Portland State University

PDXScholar

\title{
A Comparative Study of the Flathead, Cayuse and Nez Perce Tribes in Reference to the Pattern of Acceptance and Rejection to the Missionaries in the Mid-nineteenth Century
}

Mary Kathleen Branson

Portland State University

Follow this and additional works at: https://pdxscholar.library.pdx.edu/open_access_etds

Part of the History Commons

Let us know how access to this document benefits you.

\section{Recommended Citation}

Branson, Mary Kathleen, "A Comparative Study of the Flathead, Cayuse and Nez Perce Tribes in Reference to the Pattern of Acceptance and Rejection to the Missionaries in the Mid-nineteenth Century" (1995). Dissertations and Theses. Paper 4868.

https://doi.org/10.15760/etd.6744

This Thesis is brought to you for free and open access. It has been accepted for inclusion in Dissertations and Theses by an authorized administrator of PDXScholar. Please contact us if we can make this document more accessible: pdxscholar@pdx.edu. 


\section{THESIS APPROVAL}

The abstract and thesis of Mary Kathleen Branson for the Master of Arts in History were presented February 7, 1995, and accepted by the thesis committee and the department.

COMMITTEE APPROVALS:

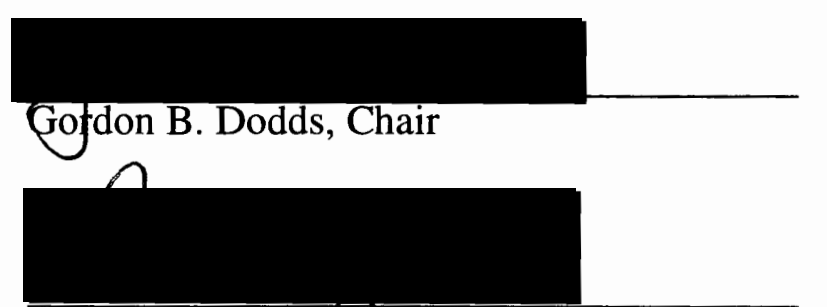

David A. Johnso

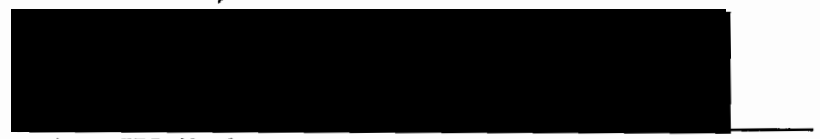

Ann Weikel

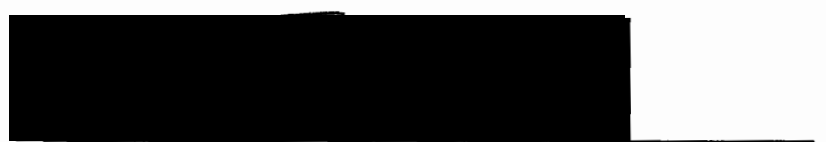

Thomas Biolsi

Representative of the Office of Graduate Studies

DEPARTMENT APPROVAL:

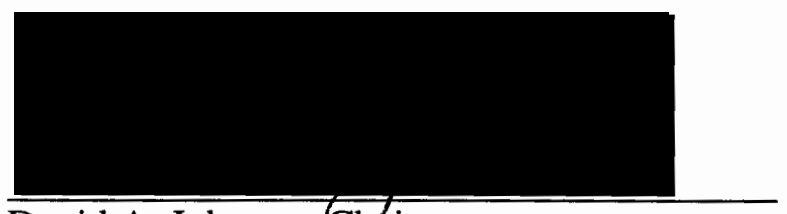

David A. Johnson, Cbair

Department of History

$* * * * * * * * * * * * * * * * * * * * * * * * * * * * * * * * * * * * * * * * * * * * * * * * * *$

ACCEPTED FOR PORTLAND STATE UNIVERSITY BY THE LIBRARY

by

on ZTounber 1995 


\begin{abstract}
An abstract of the thesis of Mary Kathleen Branson for the Master of Arts in History presented February 7, 1995.

Title: A Comparative Study of the Flathead, Cayuse and Nez Perce Tribes in Reference to the Pattern of Acceptance and Rejection to the Missionaries in the Mid-nineteenth Century.
\end{abstract}

By 1836 both the Presbyterians and the Jesuits had penetrated the Pacific Northwest. The Whitmans and the Spaldings were the first Presbyterians to settle in this region. The Whitmans settled with the Cayuse at Wailaptu near Walla Walla and the Spaldings resided at Lapwaii with the Nez Perce tribe. Although two Canadian priests were working in this region, it was not until 1840, with the arrival of Father Jean-Pierre DeSmet that the Jesuits commenced their missionary work. Fr. DeSmet initially settled with the Flathead tribe in the Bitterroot Valley of Montana.

This paper observes how the Jesuits in Montana and the Presbyterians in the Columbia basin related with their respective tribes. With each situation a pattern occurs of tribal acceptance and rejection. The different tribes were initially eager to learn from the missionaries but as the years pass by, the novelty of Christianity wore thin. What became more obvious to the tribal members was that slowly their numbers were diminishing due to disease brought over by white settlers and simultaneously their land was disappearing as the pioneers built their homes. This observation resulted directly in the Native American rejection of the Christian missionaries. The Jesuits and the Spaldings were fortunate to escape without physical harm. This was not the case, though for Dr. Marcus and Narcissa Whitman who lost their lives in the Whitman massacre. 
To understand the reasons for this rejection, this paper spends the first few chapters looking into the background of the three tribes as well as the missionaries. It then examines the three different tribes and their history with their respective missionaries, observing the reasons, both long and short term for their failures. In the final chapter the paper investigates the obvious yet undocumented competition between the Catholic and Protestant missionaries to be the sole religion in this region. Their co-existence of these two faiths was another factor which resulted in the disillusionment of the Native American tribes in this region. 


\section{A COMPARATIVE STUDY OF THE FLATHEAD, CAYUSE AND NEZ PERCE TRIBES IN REFERENCE TO THE PATTERN OF ACCEPTANCE AND REJECTION TO THE MISSIONARIES IN THE MID-NINETEENTH CENTURY}

by

\section{MARY KATHLEEN BRANSON}

A thesis submitted in partial fulfillment of the requirements for the degree of

MASTER OF ARTS

in

HISTORY

Portland State University

1995 


\section{Chapter I}

\section{Introduction}

During the nineteenth century many Christian missions were established throughout the Pacific Northwest. Although some were Protestant and others Catholic, they shared the same goal. Both were determined to convert the American Indians from their pagan religion to Christianity and, simultaneously, create a civilized community in order to better help them assimilate to the white American culture. The result of these efforts was disastrous. To better describe the reason for these negative consequences, this paper will focus on three Pacific Northwest tribes. The Nez Perce, Flatheads and Cayuse were all Plateau tribes among which missions were created. The Jesuit missionaries established their first mission in the Rocky Mountain Region among the Flatheads and the Whitmans and Spaldings settled respectively in the Columbia basin with the Cayuse and Nez Perce tribes.

All three missionary stations endured four stages in a pattern of acceptance and rejection. The first stage was a request from the Natives for missions to be settled among them. This request is important to note, for many believe these nineteenth century missionaries to have imposed themselves among the tribes, but in fact their presence was sought.. The second stage commenced with the arrival of the missionaries at their stations and continued at least four years. This could be referred to as the "honeymoon" period for the missionaries. The Indians were anxious to learn from the white men and women. They were in awe of the knowledge these newcomers possessed, such as their understanding of land cultivation. They obeyed the missionaries, abolished their "evil" customs and rapidly transformed themselves into an American civilized community. The 
third stage encompassed the change from strict obedience of the missionaries' moral codes and regulations to a complete revival of all former customs and practices deemed heathen by the Protestants. There were times during this period in which it appeared as if the Native Americans were practicing these undesirable manners with increased fervor in order to irritate the missionaries. This stage also comprised the destruction of many white creations, such as fences and mills. The last stage included the final consequences of the missionaries' involvement in the tribes. This varied in severity with the different missionaries. In the Jesuits' case among the Flatheads, they just barely escaped without encountering violence. The Whitmans, not as fortunate, were massacred along with thirteen other whites in their mission. The Spaldings, having heard of the Whitmans' fate, deserted their mission immediately for fear of their own lives.

It is pertinent to glance at the culture of each tribe, especially in areas which were affected by the establishment of Christian missions. The first aspect is the spiritual life of the tribes, probably the most significant of the Native Americans' life dimensions to be challenged by the missionaries. Also it is important to study their pattern of hunting, food gathering and warfare, for these were also critical elements in the daily lives of these natives. As important as it is to view the American Indians' background, the history of the missionaries must not be neglected either. The time period in which the missionaries were raised is important for it was at the end of the Second Great Awakening. Their family lives and early personal contacts appeared to have influenced them greatest. Their education also needs investigation, for it will assist in a better understanding of where their initial intentions derived from, especially in the instruction of the tribal members. Finally, it is easily noticeable that all of the missionaries shared a common sense of 
adventure. This was only one of many shared characteristics which resulted in similar ideals of how to convert and civilize the Native Americans of the Pacific Northwest.

In order to reach a conclusion as to why these tribes reacted as they did to the missionaries, their interactions must first be studied tracing the four steps of the acceptance/rejection pattern through the three stations. First the Jesuits' work among the Flatheads will be studied commencing with Fr. Pierre-Jean DeSmet's first visit in 1840, his return with companions in 1841 and the final abandonment and closing of the mission in 1850. Next Dr. Marcus and Narcissa Whitman will be investigated, starting with their arrival in 1836 and finishing with their murder in 1847. Finally Henry and Eliza Spalding will be studied. Often recognized as the most successful missionaries in the Northwest, the explanation for their failure requires explanation.

Many reasons have been advanced to help explain the dissolution of these three missions. The most obvious one would be the assumption that white Euro-American ideals and customs would be welcomed and could be integrated into an aboriginal culture. In hindsight it appears naive for the missionaries to believe they could accomplish this without disastrous consequences. Also there is the theory of Native resentment of the growing number of white settlers in the region. This is without a doubt a most likely explanation for the rejection of white missionaries. Along with the growing population came the devastating diseases, which wiped out great portions of the Native American population in the Northwest. This was viewed by many Indians as a purposeful result of the white arrival, hence producing even greater resentment. 
There are some explanations though, which are much less evident than the ones previously discussed. First, could it be possible that the obvious competition for religious control in the Native region caused the Indians to doubt the faith they had chosen? This paper will discuss the many different methods the Jesuits and the Protestant missionaries used in swaying the tribes to remain with their faith. The effect this had on the tribes was obvious. It did not take long for them to realize that they could use this competition to their own advantage. They were disillusioned and perplexed by the religion of Christianity, wherein they were instructed to love ones' neighbor. How were they expected to accomplish this if their mentors could not?

It is a great likelihood that with the white population increasing at the rapid pace at which it did, the tribes panicked in the thought that they might lose their culture completely. Therefore, they retaliated against the whites who were closest to them which happened to be the missionaries. Their panic appears to be justified, for one hundred and fifty years later, it is visibly apparent that they had more than enough reason for alarm. 


\section{Chapter II}

\section{Tribal Background}

One of the greatest causes of the dissolution of the Northwest missionaries was the Native realization that their culture was rapidly being altered. The missionaries' primary objective was to convert the aboriginals, and in order to accomplish this task it was necessary to civilize them first. Civilization as defined by the missionaries consisted of the implementation of white Euro-American practices, such as structured education and land cultivation. The Native American tribes of the Pacific Northwest possessed their own traditions which were deeply rooted in their heritage. In order to comprehend the rapid alterations the missionaries attempted to impose on the Native culture, it is imperative to understand the culture as it was before the arrival of Caucasians in the region.

The three tribes under investigation; the Flatheads, Cayuse and Nez Perch all possessed similar traditions and practices in their daily lives. Because they lived in close proximity to one another and interacted often over the years, many of their practices merged, so that their dissimilarities decreased. This can be shown clearly in the Cayuse adoption of the Nez Perce dialect. The Cayuse, originally having their own language, gradually embraced the Nez Perce Sahaptian dialect which was spoken by other tribes in the region as well. ${ }^{1}$ This was also the case for the Nez Perce, who after the acquisition of horses providing them with transportation, were greatly influenced by the Flathead tribe.

\footnotetext{
${ }^{1}$ Robert H. Ruby, The Cayuse Indians: Imperial Tribesmen of Old Oregon
} (Norman: University of Oklahoma Press, 1972), 12. 
They were introduced to the buffalo hunt and soon buffalo meat was added to the Nez Perce diet, as was the buffalo skin used to cover and protect their tipis. ${ }^{2}$ Many of these shared traditions throughout the region were aspects of life that the missionaries were attempting to abolish, but the more significant items which were altered by the missionaries were the Native spiritual practices, the hunting and gathering traditions and tribal warfare.

The Flathead tribe were located in the Bitterroot Valley of today's Montana. The valley was well protected by the Bitterroot Mountains, which enabled the Flatheads to resist many of the white men's diseases that penetrated the rest of the region and assisted them in deterring attacks and raids from neighboring Plateau tribes. ${ }^{3}$ The region was fertile and abundant with wildlife. The Flathead tribe was clearly a Plateau tribe, but due to the continual interactions with Plains tribes many of their customs were affected by them. The most prominent of these adopted customs was the seasonal buffalo hunt. The Flathead tribe were also commonly known as the Salish tribe. The practice of flattening an infant's forehead at birth was not a custom performed by the Montana Flatheads. How they received this name is still unknown. The explorers, trappers and missionaries all refer to this tribe as the Flatheads and it does avoid the confusion of the former name, for Salish is also the linguistic family name of the Flatheads, Spokanes and Coeur d'Alenes, as well as some Canadian tribes.

${ }^{2}$ Alvin Josephy, The Nez Perce and the Opening of the Northwest (New Haven and London: Yale University Press, 1965), 30-31.

${ }^{3}$ John Fahey, The Flatheads (Norman: University of Oklahoma Press, 1974), 5. 
The Nez Perce and the Cayuse were both located in the Sahaptian-speaking region of the middle Columbia. ${ }^{4}$ The Nez Perce received their name from the French-Canadian traders. Although the French term translates into pierced noses, there is no documented reason why the traders would have referred to the tribe by this name. It could have possibly been sign language that evoked the idea or it may have been that the Native women were wearing ornaments on their noses in this period. ${ }^{5}$ The French-Canadian fur traders also named the Cayuse Indians. When they first witnessed the beautiful band of horses, resting at the foot of the Blue Mountains, they called them the Cayuse, and after discovering their owners, the name remained with them as well. ${ }^{6}$ The name of their tribe in their native language was translated as "superior people."7 Both tribes were typical Plateau tribes, but the Nez Perce were influenced greatly by certain Plains customs, via the Flatheads. The Flatheads and the Nez Perce shared many traits due to their strong ties. Zenas Leonard noted in his journeys that the two tribes "live in the closest friendship." ${ }^{8}$ The Flatheads had much less of an impact on the Cayuse, in comparison to the Nez Perce, partially due to their geographical location and also due to the smaller size of the Cayuse. The greatest difference between the land of the Flatheads and that of the latter tribes was the presence of the Columbia River among the Nez Perce and the Cayuse. The River's most significant contribution was its the bountiful salmon runs that occurred during the spring and summer months. These tribes were dependent on salmon runs for their food supply in the summer and winter. ${ }^{9}$

\footnotetext{
${ }^{4}$ Colin F. Taylor, The Native Amercians: The Indigenous People of North America (New York: Smithmark, 1991), 100.

${ }^{5}$ Ruby, The Cayuse Indians, 6.

${ }^{6}$ Ibid., 3.

${ }^{7}$ Ibid.

${ }^{8}$ Zenas Leonard, Narrative of the Adventures of Zenas Leonard. ed. by Milo Milton Quaife (Chicago: Lakeside Press, 1934), 67.

${ }^{9}$ Haines, The Nez Perce, 12.
} 
All three tribes, for the most part, were well respected in the mid-eighteenth century. They were praised for their friendliness, honesty and high moral standards. Ross Cox, a trapper in the Pacific Northwest was partial to the manner of the Nez Perce tribe. He admired their honesty in their dealings, the way in which the men treated their wives and their natural desire for cleanliness. ${ }^{10}$ Cox also described the Nez Perce as "clean, active and smart looking." He admired their fondness for children and their respect for the elders. ${ }^{11}$ Joel Palmer, who traveled through the country in the mid-1800s, referred to the Nez Perce as an intelligent group of people, and praised the Cayuse for their good hygiene and work ethic, as well as their bountiful and beautiful horses. He also commented that the Cayuse were proud, almost haughty. ${ }^{12}$ Theodore Talbot, a serviceman from Kentucky who was on Fremont's expedition, met with the Nez Perce and the Cayuse on October 10,1843. He reported that they came riding into camp at full speed on the finest horses, and that they dressed beautifully in embroidered shirts and fringed leggings. He recalled they were a very enjoyable group, singing and dancing with the company late into the night. His greatest compliment, though was in regard to their intelligence. $^{13}$

The three tribes' physical appearances were often described in similar fashion by the first explorers, traders and missionaries. The Flatheads were described as a handsome

${ }^{10}$ Ross Cox, The Columbia River Oregon Scenes and Adventures during a Residence of Six Years on the Western Side of the Rocky Mountains.... ed. by Edgar Stewart and Jane Stewart (Norman: University of Oklahoma Press, 1957), 135.

${ }^{11}$ Ibid., 88.

12 Joel Palmer, Journal of Travels over the Rocky Mountains. March of America Fascimile Series, \#83 (Ann Arbor: University Microfilms Inc., 1966), 125-128.

${ }^{13}$ Theodore Talbot, The Journals of Theodore Talbot 1843 and 1849-1852 with the Fremont Expedition of the 1843 and with the First Military Company in Oregon Territory. ed. with notes by Charles H. Carey (Portland, Oregon: Metropolitan Press, 1931), 58. 
tribe, paying close attention to their external appearance. Ross Cox described their physical appearance: "Both sexes are comparatively very fair and their complexions are a shade lighter than the palest new copper after being freshly rubbed." He proceeded to outline their attire, with the men wearing long leggings, called mittasses. Over this was draped a dressed deerskin top; the outside seams of the leggings and shirt sleeves were fringed. Women wore a similar form of loose robe, which reached their ankles and was ornamented with fringes, beads and other decorations. ${ }^{14}$ Upon first meeting the Cayuse tribe, Joel Palmer was impressed by their good build, fine features and beautiful leather clothing. ${ }^{15}$ John Kirk Townshend, a physician and scientist from Philadelphia, came west with the Wyeth expedition in 1834. After encountering a band of Nez Perce and Cayuse who were traveling together, he was in awe of their appearance, writing:

These Indians are, almost universally, fine looking, robust men, with strong aqualine features, and a much more cheerful cast of countenance than is usual amongst the race. Some of the women might almost be called beautiful, and none that I have seen are homely. Their dress are generally of thin deer or antelope skin, with occasionally a bodice of some linen stuffs, purchased from the whites and their whole appearance is neat and cleanly, forming a very striking contrast to the greasy, filthy and disgusting Snake females. ${ }^{16}$

It is important to note, though, that this was only one band of the tribe and that appearance varied among the whole of the tribe. Not long after Townsend described the beauty of these tribes, he confronted another band of Cayuse who he found to be dirty, slothful and disgusting in appearance. ${ }^{17}$

${ }^{14}$ Cox, The Columbia River, 135.

${ }^{15}$ Palmer, Journal of Travels, 54.

${ }^{16}$ John Kirk Townsend, Narrative of a Journey across the Rocky Mountains to the Columbia River. with and intro. by Donald Jackson ( Lincoln and London: University of Nebraska Press, 1978), 162.

${ }^{17}$ Ibid., 171. 
Similar to many of the other Plateau and Plains tribes in North America, the spiritual beliefs of the Flatheads, Nez Perce and Cayuse focused upon the power of nature's elements. All of the earth's objects, animate and inanimate, possessed a spirit as strong as the Natives themselves. The earth was at the heart of their spirituality. She was the mother, always nurturing and providing for them. The Cayuse and Nez Perce shared this belief and strove to balance themselves with the rest of nature, so that they were equal with all living and non-living objects that possessed a spirit. ${ }^{18}$

Although there are many theories to how the Native Americans migrated to North America via land bridges, the Flatheads believed they descended from the great coyote. This wise animal introduced them to fire, instructed them in warding off enemies and transformed great monsters into beautiful canyons. The myths that surround the coyote help to explain the reasons for nature's different elements found in the Flathead region. ${ }^{19}$ The Nez Perce passed down similar folklore through their generations regarding the great powers of the coyote. According to popular myth, the coyote saved the region from a terrible monster that no other animal could kill. This monster had the power to engulf anything from hundreds of miles away with a deep breath. The coyote, being wise and cunning, slipped into the monster's mouth and made a fire in his stomach, and after escaping, sprinkled parts of the monster throughout the Northwest creating the different tribes. When the blood of the monster was spread throughout the Clearwater Valley, the Nez Perce tribe was created. ${ }^{20}$

${ }^{18}$ Josephy, The Nez Perce, 24.

${ }^{19}$ Fahey, The Flatheads, 4.

${ }^{20}$ H.S. Lyman, "Items from the Nez Perces Indians," Oregon Historical Quarterly 2 (March, 1901-December, 1901): 289-294. 
The ceremonies of these tribes were normally conducted in gratitude to the earth for providing them with their needs and in asking for its generosity to continue. Rarely did they take their beautiful and fertile land for granted, for everything was created for a distinct purpose. One ceremony which was practiced by the Flatheads at the beginning of the root digging season was the Prayer Dance. This dance was performed in order to obtain from the sun and earth good health and an abundance of food. ${ }^{21}$ The sun was also praised in order to attain ample meat and skins in the following seasons. Fr. Gregory Mengarini recalls the Flatheads chanting: "Sun, be so kind as to allow these animals to grow in abundance. ${ }^{122}$ Before the coming of the white man the Flatheads would occasionally sacrifice a captive to the Sun god. ${ }^{23}$ Ceremonies were practiced often in conjunction with marriages, successful hunts and as preparation for raids and wars. The Cayuse placed considerable significance on ceremonial preparations for war. Young men often fasted and purged themselves. Then, by swallowing fish-oil or gagging themselves they attempted to induce vomiting, which was normally followed by a sweat bath and a smoke of the pipe. ${ }^{24}$ Many of the rituals practiced by the plateau and plains tribes involved either dancing and/or the passing of the pipe. The smoking of tobacco was a very intimate ritual saved for only special occasions or in making peace with strangers. ${ }^{25}$

The most significant spiritual ceremony in the life of a member of one of these tribes was an individual one which occurred normally during adolescence. After ample

${ }^{21}$ Claude Schaeffer, "The First Jesuit Mission to the Flathead, 1840-1850: A Study in Culture Conflicts," Pacific Northwest Ouarterly 28 (July 1937): 239.

${ }^{22}$ Father Gregory Mengarini, S.J., Recollections of the Flathead Mission (Glendale, Ca.: A.H. Clark and Co.,, 1977), 157.

${ }^{23}$ Fahey, 13.

${ }^{24}$ Ruby, 13

${ }^{25}$ Nicholas Point, Wilderness Kingdom. Indian Life in the Rocky Mountains: 1840-1847; the Journals \& Paintings of Nicholas Point, trans. and intro. by Joseph P. Donnelly (New York: Holt, Rinehart \&Winston Press, 1967), 147 
preparation with an elder, a young boy or girl would make a journey up to a top of a mountain or another secluded location and remain there for a sufficient amount of time, usually three to five days. In this time they were to dance, fast and sleep, but, most importantly, await the coming of their spiritual vision that would serve as their spiritual guide for the rest of their lives. The Flatheads called this vision a sumesh and the Nez Perce referred to it as a person's wyakin. These visions often appeared in dreams and in hallucinations and took on the forms of animals or other elements of nature. ${ }^{26}$ The vision could also present itself in the physical form of a living animal or a natural occurrence, such as a bolt of lightening. The vision was often induced by the fear of being alone combined with the physical effects of fasting. ${ }^{27}$ Often the animal or element taught the adolescent a song that was in turn relayed to the rest of the tribe As soon as the youth received their sumesh they were allowed to return to the tribe. The vision often prophesied the future role of the youth in the tribe, either as a man of medicine or warrior. ${ }^{28}$ Although most Native Americans were named at birth, this name was simple, usually in accordance with the first thing that was seen or heard. Later when the youth received their vision, their name was changed in accordance with the element of the vision, so often these young men and women would be known throughout the tribe as "red fox" or "white raven." This name was customarily what the youth would be addressed by for the remainder of his or her time. ${ }^{29}$ Among the Nez Perce, when the youth came home with the new vision, he or she did not reveal it to anyone in the camp, but waited until the Guardian Spirit Dance, in which each youth would dance and give hints to what their wyakin was until it was solved by the others. In these dances the youth, in order to

${ }^{26}$ Mengarini, Recollections of the Flathead Missions, 161-162.

${ }^{27}$ Josephy, 26.

${ }^{28}$ Robert J. Bigart, "A Cultural History of the Salish, Flathead Indians of Montana: 1805-1891" (Ph.D. diss., Harvard University, 1969), 8.

${ }^{29}$ Mengarini, 167. 
become more a part of their new spirit, often dressed and painted themselves so as to resemble their wyakin. ${ }^{30}$

Other significant spiritual beliefs revolved around their conception of death. It was the Flathead creed that upon death only half of the man or woman died and the remaining half, which is called the Singappeus continued living. This portion of the spirit traveled to rest with the supreme being, Arrotkan. The Singappeus of an evil man journeyed to another location, which although not believed a wretched space, was without Arrotkan, and therefore inferior. ${ }^{31}$ Cox's interpretation of this abstraction deviated slightly from the above definition. He understood that a good person who died, spent the afterlife in a beautiful country where there is perpetual summer and upon arrival he or she was greeted by the rest of their family. The evil Flathead was destined to spend his or her afterlife in an eternally snowed-in land. They would forever shivering from cold, thirsty and hungry, and would have no hope of escaping. ${ }^{32}$

In each tribe there was also much spiritual emphasis placed on the shamans and herbal doctors. The Flathead shamans were referred to as Tlekinlsch. The shaman cured ill members of the tribe by dressing up in costume, dancing around and shaking rattles or other noisemakers in order to drive away the evil spirits. ${ }^{33}$ These men were greatly respected by the rest of the Flatheads for their supernatural abilities ${ }^{34} \mathrm{Dr}$. Marcus Whitman later described a ceremony in which a shaman was aiding an ill Nez Perce:

\footnotetext{
${ }^{30}$ Josephy, 27.

${ }^{31}$ Mengarini, 154-155.

${ }^{32}$ Cox, 140.

${ }^{33}$ Fahey, 15.

${ }^{34}$ Mengarini., 157.
} 
Calling on one of these sorcerers who calls to his aid a number of persons to sing $\&$ beat upon sticks with a horrible noise, while he goes through with singing talking contorting expressions supposed to be repeating what he knows of the language of the former rase of men as delivered to him by the beast bird reptile orfish. $^{35}$

He then goes on to explain that in order to finally extract the pain from the patient, the shaman touches the wounded or painful spot. ${ }^{36}$

By the nineteenth century the plateau tribes had mastered an annual cycle of hunting and gathering food. Each spring the men would cross the Rocky Mountains into the Great Plains in search of buffalo. Before the 1840s, the Flatheads hunted bison almost exclusively west of the Rockies, but after the acquisition of firearms and ammunition they became careless and assisted in the destruction of the bison population in this interior region. However, it was their belief that the loss of the buffalo was not their fault, but a response to the spiritual imbalance caused by the white man's presence in their valley. Regardless, the tribe was forced to hunt for these animals on the east side of the Rockies, from this time forward. ${ }^{37}$ The Nez Perce and Cayuse did not participate in the buffalo hunts east of the Rockies until after they acquired horses in the early eighteenth century. Even at this point, it took time to accustom themselves to these new animals and take advantage of their mobility. The horses provided the Nez Perce with transportation to buffalo country, where they were greatly influenced by the plains tribes and those in close proximity, such as the Flatheads. One effect that appeared not long after the Nez Perce began regularly hunting buffalo was their use of tipis, instead of

${ }^{35}$ American Board Commission of Foreign Affairs Letters and Papers Concerning the Oregon Indians, vol. 138, vol. 3, 709.

${ }^{36}$ Ibid.

${ }^{37}$ Fahey, 9. 
community houses, because of their portability. ${ }^{38}$ The Nez Perce and Flatheads often united in their annual hunts, so as to appear more threatening to the violent and fierce Blackfeet. ${ }^{39}$ There was fierce competition in this land for bison. The Blackfeet, who were known for both their large number of warriors and ferocious battles, were accustomed to hunting in this region alone. This opposition resulted in many bloody battles, with the plateau tribes normally losing many more warriors than the Blackfeet. It was often speculated why plateau tribes, such as the Flatheads, felt it necessary to hunt for these animals east of the Rockies, when they could most likely survive on the wildlife in their own region. Ross Cox pondered on this dilemma when he visited with the Flathead tribe:

The lands of the Flatheads are well stocked with deer, mountain sheep, bears, wild fowl and fish; and when we endeavored to induce them to give up such dangerous expeditions and confine themselves to the produce of their own country, they replied that their fathers had always hunted on buffalo grounds. . and they would not now abandon a practice which had existed for generations among their people. ${ }^{40}$

The Cayuse do not appear to have joined the hunting expeditions east of the Rockies as frequently as the other tribes of the region. Their horses were used less for hunting and more for leisure. They were renowned for their beautiful ornamented horses, as well as other accouterments associated with riding. They were the tribe who initially introduced horses to the Nez Perce, who in the end became superior selective breeders. ${ }^{41}$ Some historians have theorized that they enjoyed breeding horses and placed effort into breeding two-toned horses or ones with polka-dots. ${ }^{42}$ Instead of hunting buffalo, which

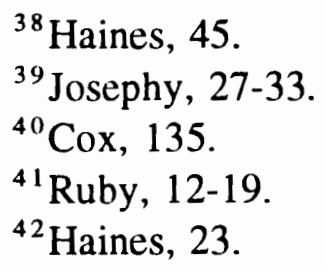


they often acquired through annual trades, the Cayuse spent more time securing salmon, and other species of fish during the months of spring and summer. Much of the salmon was dried, packed and stored for the winter months to help avoid hunger. ${ }^{43}$ The Nez Perce also provided subsentence for their tribe by obtaining salmon and storing it for the winter. Along with bitterroot and camas root, it was one of the tribe's primary staples. ${ }^{44}$

The Flatheads' dwellings while on the hunt were very similar to those which were at the main camp. They were made of slim poles that ranged from twenty to thirty feet in length and were separated at the bottom by about fifteen feet. Leonard wrote that they "joined together at the top, forming a structure in the shape of a roof of a common dwelling house." The roofs were often covered with buffalo hide and in the center of the structure a fire continually burned. These habitats were easily taken down and reconstructed if it were necessary to relocate swiftly. ${ }^{45}$ As stated before, the Nez Perce also adopted a similar form of habitat when traveling and hunting in the plains. Ross Cox describes the dwellings as varied in size with a hole at the top for both a chimney and a window. He commented that they were free from vermin and not difficult to transport. ${ }^{46}$ The Cayuse, however, lived in mat houses in the summer months and semi-subterranean dwellings during the winter. These dwellings were also considered temporary and were easily transported. ${ }^{47}$

Not long following the acquisition of firearms and ammunition, the Flatheads became renowned in their region for their fine marksmanship. Because the tribe often

\footnotetext{
${ }^{43}$ Ruby, 8-12.

${ }^{44}$ Haines, 11-13.

${ }^{45}$ Leonard, 55.

${ }^{46} \mathrm{Cox}, 88$.

${ }^{47}$ Ruby, 4-5.
} 
hunted deer in the Bitterroot Valley, which required a much more precise mark, hunting bison came easy to them. ${ }^{48}$ Father Nicholas Point, who spent time with the Flatheads on a couple of their hunts, commented on the periods where the hunters were forced to develop new techniques: "It is when food is scarcest that the hunt is most interesting to observe. Neither dogs nor hunters are ever more vigilant, more industrious, more alert, more corageous." ${ }^{49}$ Hunting was genuinely loved by the Flatheads. The time spent preparing for it, the stories related after, and the hunt itself were very much a great part of Flathead life. The Nez Perce also became very fond of hunting bison on the plains, for it proved bravery among the young tribesmen and publicized their role as providers for the community.

Similar to other tribes in the Pacific Northwest region, the Flathead, Nez Perce and Cayuse women passed their time in the spring digging roots and picking berries. The roots were dug up with a sharpened stick or wooden paddles and pounded flat and cooked to form a cake. ${ }^{50}$ These cakes were then either eaten, stored for the winter, or traded to different tribes for other items. Fr. Nicholas Point, having spent much time hunting with the Flatheads, had consumed a fair share of root delicacies, found the bitterroot too bitter for those not accustomed to it. Of the camas, he wrote, that although it tastes fine, "its digestion is accompanied by very disagreeable effects for those who do not like strong odors or the sound that accompanies them." ${ }^{51}$ It could be argued that the digging of roots and the picking of wild berries was even more of a necessity than the

${ }^{48}$ Claude E. Schaeffer, "Acculturation Study of the Indians of the Flathead Reservation of Western Montana" (Submitted to the Commissioner of Indian Affairs, Washington D.C., 1967), 20.

${ }^{49}$ Point, Wilderness Kingdom, 151.

${ }^{50}$ Fahey, 12.

${ }^{51}$ Point, 166. 
meat obtained through the buffalo hunts, for it was seasonably dependable and limitless in its quantity.

War among the tribes of the plateau region was one of the most significant aspects in the culture. Inter-tribal battles resulted for many different reasons. Most often a battle broke out in retaliation for the raiding of horses or other personal injuries. Other times war was caused when a tribe felt their land threatened. This was one of the reasons for the continuing Blackfeet-Flathead wars of the nineteenth century. As the Flatheads moved into the plains to hunt buffalo, the Blackfeet retaliated fiercely. This was also the case for the Cayuse, who, when expanding further down the Columbia River, pushed the Molallahs into the Willamette Valley, creating animosity among the Molallahs, which resulted in many scrimmages throughout the century. ${ }^{52}$ Of the three tribes being studied, the Cayuse were probably most known for their warrior-like mentality. They rarely fought to gain land, but instead to display personal and tribal power. Their captives were brought to the camp and enslaved, increasing their tribal stature. Within each band of the Cayuse, of which there were three in the nineteenth century, there were both head chiefs and war chiefs, the latter achieving their title through the display of ability, good judgment and courage in battles. Their primary enemy was the Shoshoni tribe, with whom many of their battles occurred in reaction to horse theft. However, they also raided as far south as Northern California where they captured Shasta slaves. The ceremonies, which took place previous to the wars, were elaborate, consisting of physical deprivation of the warriors, long speeches in varied dialects from the chiefs, face painting and dressing in accordance. ${ }^{53}$

$$
\begin{aligned}
& { }^{52} \text { Ruby, } 6 \\
& { }^{53} \text { Ibid., } 7-15 .
\end{aligned}
$$


The Nez Perce warfare was similar to that of the Cayuse, yet appeared to have lacked the intensity. The desire to raid tribes, steal horses, capture slaves and occasionally scalp the head of the enemy was required to prove their manhood and increase their status among the tribe ${ }^{54}$ To become a chief among the Nez Perce's, one must either display leadership among the people or power in war. ${ }^{55}$ The Nez Perce traditional enemies were the Coeur d'Alenes to the north and the Shoshoni to the south. ${ }^{56}$ Frequently in their larger wars with the fierce Western Shoshoni, whom the Nez Perce referred to as Teewalka , meaning "an enemy to be fought," the tribe would engage the Cayuse or the Walla Wallas to ally with them in these battles, so as to increase their chance of victory. ${ }^{57}$ The only other time that the Nez Perce were forced to fight was when they commenced hunting bison in the plains and were forced to confront the Blackfeet.

Although by the mid-1840s many different tribes in the Northwest hunted buffalo in the Plains region, it was the Flatheads, due to their permanent location, who received the vengeance of the Blackfeet most frequently. ${ }^{58}$ Different from the Cayuse and the Nez Perce, the Flatheads almost always appeared to have been defensive warriors. The Blackfeet were so numerous and fierce, that Flathead chances for victory in war with this tribe were slim. One military method which was practiced by the Flatheads, mentioned previously, was consolidation with a couple of neighboring tribes in these wars to secure success. The Flatheads' threatened existence in the nineteenth century can be displayed

${ }^{54}$ Josephy, 33.

${ }^{55}$ James Fraser Cocks, The Selfish Savage: Protestant Missionaries and Nez Perce and Cayuse Indians, 18355-1847 (Ann Arbor: University Microfilms International, 1975), 94.

\footnotetext{
${ }^{56}$ Haines, 17.

${ }^{57}$ Josephy, 21.

${ }^{58}$ Fahey, 11.
} 
by gauging the steady decreases in population of the tribe. This tribe, which at one time may have been as large as ten thousand people, continued to drop in numbers, a fact that Ross Cox and many others blamed on these wars. ${ }^{59}$ Zenas Leonard also points out that the battles which occurred with the Blackfeet were unavoidable and appeared to have been accepted as simply another component to hunting on the Plains ${ }^{60}$ Although the Flatheads' primary enemy was the Blackfeet, they were known to have scrimmages with other neighboring tribes as well. Cox provided detailed descriptions of the hierarchical order in the Flathead tribe in his journal. He explains that the war chief, unlike the principle chief whose position was hereditary, was elected each year. This war leader only held authority during battles and at camp was treated similarly to the other warriors. ${ }^{61}$ The Flatheads, although losing many lives to the Blackfeet who acquired firearms before them, were known throughout the region as both skillful and brave warriors. ${ }^{62}$

It is imperative to understand the basic components of the lives of the Flatheads, Cayuse and Nez Perch in order that the changes which occurred following the arrival of the missionaries and white population can be better understood. Many of their daily customs and practices were threatened or abolished by the missionaries in order to create a more civilized environment, which would theoretically result in the desire for Christian conversion.

\footnotetext{
${ }^{59}$ Cox, 133-34.

${ }^{60}$ Leonard, 55.

${ }^{61} \mathrm{Cox}, 136$.

${ }^{62}$ Mengarini, 169.
} 


\section{Chapter III}

\section{Missionary Background}

The early lives of the Pacific Northwest missionaries is a very significant element in understanding their intentions for the native tribes and the reasons why they conducted themselves as they did. For many of them it was their early lives and influences which shaped their ideals concerning the Christianinizing and civilizing of the "savages" in the west. The intentions of the Presbyterian and Jesuit missionaries of the Pacific Northwest were virtuous and innocent, for their belief was that they could only improve the lives of these "heathens" by introducing them to the word of God and white civilization.

Robert F. Berkhofer, author of Salvation and the Savage, explains that after 1812 there was a much greater sense of nationalism. This combined with improved modes of transportation resulted in the advancement of missionaries across the nation. It was also in this period that the feeling of "manifest destiny" was growing, encouraging these devoted Christians to move west to the Pacific Ocean. 63 The Second Great Awakening which occurred at the turn of the century was yet another influence which lead many Christian groups on the East Coast to realize that their purpose of existence was to spread the "good news" to the far corners of the world. Although the Jesuits and the Presbyterians were among the first missionaries in the Pacific Northwest, the notion of Christian conversion among aboriginal tribes was not a new one. "The Society for Propagating the Gosphel Among the Indians and others in North America" was

${ }^{63}$ Robert F. Berkhofer, Jr. Salvation and the Savage An Analysis of Protestant Missions and American Indian Response. 1787-1862 (Lexington: University of Kentucky Press, 1965), 2. 
established in 1787 and the next year a similar organization called the "Society of the United Brethen for Propagating the Gosphel Among Heathen" commenced its work. These were followed by many other societies, of which all shared the same purpose of preaching the gospel. 64 In all of these groups it was soon realized that in order for Christian conversion to take place, civilization was necessary. Berkhoffer defines this notion of civilizing as "an upward unilinear development of human society with the United States near the Pinnacle." 65 This same realization was found in other parts of the world, such as in the Jesuit work among the natives of Paraguay. Father Pierre-Jean DeSmet based much of his work in the Pacific Northwest on what was learned about civilizing native tribes in Central America. 66

During this period, the general American attitude concerning the Native Americans portrayed them as at the lowest point of civilization where even the most admired aspects of their culture were far inferior to those white civilization. Stephen Riggs, a missionary among the Sioux, makes this point in writing to David Greene of the American Board Commissioners of Foreign Missions(A.B.C.F.M.) on April, 29, 1846:

As the tribes and Nations the Indians must perish and live only as men! With this impression of the tendency of God's purposes as they are being developed year after year, I would labor to prepare them to fall in with Christian civilization that is destined to cover the earth. 67

\section{${ }^{64}$ Ibid., 3.}

${ }^{65}$ Berkhofer, Salvation and the Savage, 4-6.

${ }^{66}$ H.M. Chittenden and A.T. Richardson,, ed., Life. Letters and Travels of Father Pierre-Jean DeSmet. S.J. 1801-1873, Missionary Labors and Adventures among the Wild Tribes of the North American Indians, Embracing Minute Descriptions of their Manners, Customs, Games, Modes of Warfare and Torture, Legends. Tradition etc. All from Personal Observation Made during Many Thousand Miles of Travel, with Sketches of the Country from St. Louis to Puget Sound and Altabrasca (New York: Francis P. Harper, 1904), 328-330.

${ }^{67}$ Berkhofer, 7-11. 
These were the notions circulating in the missionary societies, as well as much of the white communities in the United States. Similar views were shared by the Roman Catholics in Europe. Their missionary work had already penetrated many territories of the world through not only the Jesuit order but the Franciscans also. The Jesuit missionaries of the Pacific Northwest shared these notions, therefore desiring the best life possible for the natives of the region, which was one of a civilized, European white community with the Christian God at the core of it.

Dr. Marcus Whitman was the first of the missionaries to have displayed strong interest in crossing the continent and establishing missionaries in the west. He was born in Rushville, New York, on September 4, 1802. He was one of five children. He was unable to maintain close ties with his siblings, for in 1810 his father, Beza Whitman, died leaving his mother with five children under the age of 12 . She was forced to send Marcus away to his father's brother's home in Cummington, Massachusetts. It is very likely that had Marcus Whitman remained in Rushville with his mother and siblings he would have never became a missionary, for it was in Cummington, under his uncle's supervision, that his religious education commenced. He remained there until 1815 , at which time he moved to Plainfield, where he lived with Colonel John Packard and attended school. In Plainfield, under the strong influence of the Reverend Moses Hallock, who was both his minister and instructor, young Marcus felt he had truly found God. In the small religious school which Hallock ran, only three hundred and four students graduated, of which fifty eventually became ministers and seven missionaries, proving the strong religious predominance within the school's curriculum. Later in 1834, Marcus wrote to the A.B.C.F.M. of the profound effect Hallock had on his spiritual beliefs. He wrote, "I 
attended the administrations of Rev. Moses Hallock at which time I was awakened to a sense of my sin and danger and brought by Divine grace to rely on the Lord Jesus for pardon and salvation." 68

Although it was clear Whitman wished to become a minister, he was put off by the amount of schooling required, which was four years of college and two to three additional years in the seminary. He instead chose the vocation of medicine, in which he spent two years, 1824 and 1825, studying under Rushville's principle physician, Dr. Ira Bryant. This study, plus sixteen weeks of classroom training, was all that was required to become a "doctor." After receiving certification, Marcus spent a year unsure of what his next move would be. Finally, he decided it was too late in his life to pursue a career in ministry and he returned to the College of Physicians and Surgeons of the Western District of New York to complete his medical training.

It was not until 1834 that events started coming together successfully for $\mathrm{Dr}$. Marcus Whitman. Samuel Parker, a missionary among the Pawnees returned home to Ithaca, New York, in search of a partner to explore Oregon with him. The Board, impressed with his prior missionary work, granted Parker his request. Parker inquired throughout the Western New York region for assistance in this project, and one of his appeals was to the Presbyterian church in Wheeler, which is where he found Dr. Marcus Whitman ready and willing to make the journey. After the two met, Whitman immediately wrote the Board requesting that he be recommended for this position. In January of 1835 , the A.B.C.F.M. met to review Whitman's request. He was immediately accepted for the position and he and Parker decided to meet in St. Louis on April 1, 1835

${ }^{68}$ Clifford Drury, Marcus and Narcissa and the Opening of Old Oregon (Glendale, Ca.: A.H. Clark Inc., 1973), 61-69. 
to commence their journey. The weekend of February 22,1835 , Whitman spent time with the Prentiss family. During this weekend visit it was decided that he and Narcissa would engage to marry. 69

Early differences between Parker and Whitman arose during their wait for departure. They desperately needed money to finance their trip. Whitman was eager and optimistic in his attempts to secure funds. Parker, who was fifty-six years old and had worked as a missionary prior to this endeavor, approached the situation with a much more laxadaisical attitude. He, believing that he understood the futility of attaining financial support, was lethargic in his attempts. Regardless of their differences, the two departed Liberty, Ohio, under the protection of the American Fur Company on May 14, 1835. In the beginning the men in the caravan were unfriendly to the missionary explorers. Later, though, when cholera struck, the party was grateful to have a doctor among them. Parker wrote:

Three of the company died; and several others barely survived, through the blessing of God upon the assiduous attentions of Dr. Whitman, my associate, and the free use of powerful medecines. And had it not been for his successful practice, the men would have dispersed and the caravan would have failed of going to the place of rendezvous 70

The 1835 rendezvous took place in one of the favorite spots of both the traders and tribes: the Greene River, a tributary of the Colorado River. The rendezvous attracted most all interior tribes as well as the American Fur Co., the Hudson's Bay Co. and independent trappers. It was a social event, as much as a trading one. Ten days were passed drinking, trading, gambling and telling stories. Whitman and Parker arrived on

${ }^{69}$ Drury, Marcus and Narcissa, 92-96.

${ }^{70}$ Ibid., 115-124. 
August 12,1835 , a month later than expected. They immediately met with the Flatheads and Nez Perce, who were extremely gladdened to see these pious men and very anxious to have them come settle among their tribes to teach the good word. Whitman wrote on August 16, "We had a talk with the chiefs of the Flatheads and Napiersas [Nez Perce] tribes, in which they expressed great pleasure in seeing us and strong desires to be taught." 71

Whitman immediately requested to return to the states to seek out more associates to return with him and establish missions. On the seventeenth the men met one more time with the Nez Perce, excluding the Flatheads, which would indicate their decision to work among only one tribe. He departed ten days later on August 27th in the company of two Nez Perce boys and arrived in St. Louis on November 4th. Two months later in January, he and Narcissa were married in a church in Angelica. His next mission was a difficult one. He needed to find another couple who would accompany Narcissa and himself on the joumey to Oregon and establish a Presbyterian mission. 72

Like Marcus Whitman, Narcissa Prentiss was also born in New York, in Prattsburg on March 4, 1808. She was raised among eight siblings, being closest to her younger sisters, Jane and Harriet. Her parents were both strong figures in her early life, especially her mother. Her father was a probate judge and a county supervisor for at least one term. ${ }^{73}$ Her mother, Clarissa Prentiss, was intelligent, pious and gifted in conversation. She, like many women of her region, discovered evangelicalism during the Second Great Awakening. Clarissa was very strict in the Christian upbringing of her

${ }^{71}$ Ibid., 133-135.

${ }^{72}$ Drury, Marcus and Narcissa. 137-147.

73Ibid., 99-100. 
children. They were all very active in church, Sunday school and daily prayers. ${ }^{74}$ She selected their reading literature, making sure that they contained proper theological themes. At the age of four, Narcissa was already a member of the Youth Missionary Society. There is more than enough proof to suggest that Clarissa conditioned her children for a life revolving around service to the Lord. 75

When Narcissa was sixteen, she remembered hearing her call to be a missionary. She later was even able to pinpoint "the first Monday of Jan., 1824" as the exact day. Other influences were the Reverend James H. Hotchkin and an American missionary to India named Harriet Boardman. Narcissa was a diligent and intelligent student, studying at Franklin Academy. Later, she studied in Mrs. Emma Willard's Female Seminary in Troy, New York. This school specialized in the training of teachers. The next few years were spent teaching in county district schools. She was almost twenty-seven when she married Marcus Whitman, which at this time was a very late age for a woman to marry. 76

The other half of this Presbyterian quartet was Henry Harmon Spalding and Eliza Hart Spalding. They met in 1830, fell in love and were married, both knowing they would devote their lives to the Lord's service. Henry Harmon Spalding was born in Wheeler on November 26,1803 . At fourteen months of age he was given to another family until he was seventeen. Around 1820 he went to live in Prattsburg with Ezra Rice. He, like Narcissa Whitman, was greatly influenced by the Presbyterian church minister Hotchkin. From 1825-1831 he attended Franklin Academy. Following this training he decided to

74Julie Roy Jeffrey, Converting the West: A Biography of Narcissa Whitman (Norman: University of Oklahoma Press, 1991), 14-15.

${ }^{75}$ Ibid., 17-18.

${ }^{76}$ Drury, Marcus and Narcissa, 104-111. 
attend Hamilton College in Clinton, New York, but soon discontent with the courses and students at the school, he transferred to Western Reserve College in Hudson, Ohio. ${ }^{77}$ It was while he was at Western Reserve College that he met Eliza Hart of Holland Patent, New York, who may have been studying at the neighboring Female Seminary in Clinton.

The two married in October of 1833 following Henry's graduation. Henry decided to continue his religious education by entering the Presbyterian-affiliated Lane Theological Seminary. It was necessary to perform manual labor while in school to receive room and board. Henry, therefore, learned the trade of the printing press. This would later prove advantageous when the mission at Lapwaii received the first printing press in the Northwest. 78 After two years of study, Henry decided to forego his senior year and offer his services to the A.B.C.F.M. His initial request was to work among the Osage Indians. He did not receive this appointment until the fall of 1835 . In the meantime he was ordained in August by the Presbytery of Bath. It was also during this period that Spalding first learned of Whitman's need for another couple to establish a Protestant mission in Oregon. His immediate response was negative, due to harbored resentment of Narcissa and Marcus's marriage. He had once been in love with Narcissa, and had gone as far as to ask her hand in marriage, which she declined. Soon it was February of 1836 and Whitman was very anxious to return west, not to mention that he had promised to return the Nez Perce boys within the year. He was desperate for another couple; therefore, with the Board's permission, he approached Henry Spalding for the job. He rushed to Prattsburg to find the Spaldings, but they had departed the previous day for their mission among the Osages. He found them, though, the following day, only fifteen miles outside

${ }^{77}$ Clifford Drury, ed. The Diaries and Letters of Henry H.Spalding and Asa Bowen Smith Relating to the Nez Perce Mission (Glendale, Ca.: The Arthur H. Clark Co., 1958), 228.

${ }^{78}$ Drury, Spalding and Smith, 229. 
of Prattsburg and upon meeting with Henry and Eliza, pleaded with them to come west. Henry Spalding eventually relented, most likely after certain conditions were set. One condition which was probably decided upon at this meeting was the establishment of two separate missions. Later William H. Gray would write in a letter to David Greene of the A.B.C.F.M. relaying Spalding's reasoning as to why his mission was so far from the Whitmans. Spalding is reported as telling Gray, "Do you suppose I would have come off here all alone a hundred \& twenty miles if I could have lived with him or Mrs.

Whitman?"79 Regardless of any ill feelings, it was finally settled, the two couples would cross the continent as soon as possible and establish Protestant missions among the Nez Perce and possibly another Native tribe, unknown to them.

The final Presbyterian missionary, Eliza Hart Spalding, has the most difficult early life history to trace. She was born in what is now Berlin, Connecticut on August 11, 1807. Little is known regarding her childhood and education. Early in her education it is recorded that Eliza excelled in homemaking crafts, such as making soap, spinning, weaving and cooking. ${ }^{80}$ Eliza would later utilize these skills while working among the Nez Perce women. In September of 1826 Eliza proclaimed her faith to the Presbyterian church of Holland Patent. Eliza was aware from that time that she would always remain a devout women leading her life in a Christian manner. She first heard of Henry Harmon Spalding through her church. It was common knowledge that this man was a very pious individual who wished to meet a woman who shared these common views. ${ }^{81}$ After Eliza and Henry met, they lived in close proximity for two years before their marriage. Once

${ }^{79}$ Drury, Marcus and Narcissa, 231.

${ }^{80}$ Clifford Drury, ed.First White Women Over the Rockies: Diaries. Letters and Biographical Sketches of the Six Women of the Oregon Mission who Made the Overland Journey in 1836 and 1838 (Glendale, Ca.: Arthur H. Clark Co., 1963), 173-174.

${ }^{81}$ Ibid, 174. 
married, Eliza assisted in financing Henry's education at the Lane Theological Seminary by opening a boarding house, where tenants were charged three dollars a day. She did all the cooking herself and even offered to take a teaching job if necessary. Henry comments on this devotion in a postscript in a letter to her sister Lorena, "Mrs. S. is inclined to teach this season. Our circumstances do not demand it. She thinks she can be doing more good, and at the same time, pursue her regular studies. "82 Eliza Spalding was always willing to give her time for the well-being of other people as is illustrated most clearly when viewing her work and her relations with the Nez Perce.

Unlike the Presbyterian missionaries, the Jesuits had a much older background. They had been involved in the training and distributing of missionaries around the world since the sixteenth century. They set up small colleges throughout Europe with the intent of educating the young men and protecting them from the newly popular Protestant religion. The Jesuit missionaries of this period were similar to one another in their love of adventure, bravery and strong faith in the Lord. To become a foreign missionary, a young man would have to prove his intellectual ability. He would then be sent to such places as Goa, Lima or Mexico City to spend the rest of his life instructing in the Catholic faith. The other alternative was to work among the natives of a designated region, instructing in catechism, baptizing and performing masses. 83 These new missionaries were advised to exaggerate the positive aspects of the missions in their annual reports sent to Rome. In a letter to missionaries in Malaccas, their superior wrote: "Write detailed of the work on Conversion and let it be of edifying matters: remember that many people will read these letters." 84 This is one piece of advice which Pierre-Jean DeSmet took whole-heartedly

82Ibid, 176.

${ }^{83}$ John Cedric H. Aveling, The Jesuits (New York: Stein \& Day, 1982), 105-147. ${ }^{84}$ Aveling, The Jesuits, 148. 
into his work in the West. One prevailing occurrence which plagued the Jesuits throughout their history was their late arrival in each particular region. With the exception on Japan, the Jesuit missionaries followed other religious groups by some twenty to forty years in each territory. Because of this they were often disliked and regarded as intruders by other established missionaries. 85

Fr. Pierre-Jean DeSmet is often considered one of the most significant white men to have crossed the Rockies in the nineteenth century. He is renowned for his good relations with the Pacific Northwest Indians. His goals for these missions were vast, proving later to be unrealistic. He was impulsive and very much an optimist. These traits, although normally appealing, were a definite contribution to the later disillusionment of the region's natives as well as the Society of Jesus.

DeSmet was raised in the small village of Termonse in East Flanders. Bored with ordinary life and inspired by a missionary from America, DeSmet offered his services as a missionary to America. He was ordained at age twenty six and after enduring unusual illness, extreme boredom and frustration with his job's paperwork, he left St. Louis and returned to Europe after only five years. Upon arrival in Europe, at his own request he was dismissed from the order. 86 Soon, though, he was restless in Belgium and once again desired to work among the natives of North America. Fortunately, Father Johann Roothaan was liberal, and readmitted the indecisive DeSmet in 1837. At this point he was stationed in Council Bluffs at a mission among the Potawatomie tribe. This mission, like many other of DeSmet's commitments, was short-lived 87

${ }^{85}$ Ibid., 149.

${ }^{86}$ Wilfred P. Schoenburg, Paths to the Northwest: A Jesuit History of the Oregon Province (Chicago: Loyola University Press, 1982), 6.

${ }^{87}$ Ibid., 6-7. 
It was in Council Bluffs where DeSmet was first approached by Peter Gaucher and Young Ignace who had traveled from the Bitterroot Valley to plead with DeSmet to return to the region with them. It did not take much to secure a promise from DeSmet, for this was an opportunity he had dreamed of. He proceeded to obtain the appointment from the Bishop and -which was much more difficult- secure the funds necessary for the journey. Roothaan was not at all pleased with the possible appointment of DeSmet to the Rocky Mountain Mission. He had witnessed DeSmet's lack of commitment once before and felt there were other candidates much better qualified. Roothaan referred to this problem in a letter written in 1839 to Fr. Peter Verhaegen, vice provincial of the Missouri Vice Province. He stated, "Perhaps, there are Fathers among you much better fitted to go on such an expedition than those who recently came to you from Europe," a statement obviously referring to Fr. DeSmet. 88

DeSmet finally did attain the appointment but not without competition from Jesuits as far away as Rome. He departed on his first journey on March 27, 1840 and after writing glorified reports of the Pacific Northwest's need for salvation, he returned in 1841 with two more priests and three brothers. Although Brothers Classens, Specht and Huet, as well as Fathers Nicholas Point and Gregory Mengarini, were significant in the establishment of St. Mary's Mission in the Bitterroot Valley, they did not compare to the noteworthiness of Fr. DeSmet and later, Fr. Ravalli. It should be noted, though, that both Point and Mengarini left detailed descriptions of their lives among the Flatheads for future generations and Point left numerous paintings and sketches as well.

${ }^{88}$ Ibid., 7-8. 
It was Father Ravalli, though, who left the most positive impact on the Flathead tribe. Unlike DeSmet, he did not promise anything he could not follow through with and did all that he could to aid the natives in their religious instruction and civilization. He learned many different trades in Italy, where he was born in 1812 in the town of Ferrara. He was educated in art, literature, medicine, philosophy and farming. Not only did he arrive in the Bitterroot Valley as the first doctor, but he was also a skilled carpenter, building the first saw and flour mill in the region. He was an accomplished artist as well which is proven by his simple but elegant wooden sculptures. His paintings also covered the walls of the mission church and it is said that he pulled the hairs off of his favorite cat to make his paint brushes. ${ }^{89}$ All of these qualities were of benefit to the Flatheads and the other Jesuits, but it was Ravalli's devotion to the Flatheads that in the end would be his greatest attribute.

The missionaries crossed the continent with only virtuous intentions for the Pacific Northwest tribes. They believed that by introducing the natives to the good word of God and white civilization, they would improve their daily lives greatly. Although innocent, this notion was naive and not well thought through and for these flaws, the missionaries would find themselves frustrated and perplexed with the tribes' lack of interest in their religion and lifestyles.

89 Walter Taylor, "Flatheads Trekked 800 Miles to Welcome Fr. DeSmet When he Came to Found their Mission," The Hardin Tribune Herald, 28 March 1936, 5. 


\section{Chapter IV}

\section{The Flatheads and the Jesuit Missionaries: $1840-1850$}

After receiving authorization from the Society of Jesus, Father Pierre-Jean DeSmet traveled west in the spring of 1840 to investigate the Native American tribes of the Rocky Mountain region. He completed this journey under the protection of the American Fur Company. Not long into the expedition Fr. DeSmet became very ill with a high fever. Due to the fever, he was urged to return home, but refused such suggestions for he was eager to meet with the western Indians. 90 Upon arrival at Pierre's Hole, where he was to meet the Flatheads, he could not have been more thankful that he did not entertain the thought of returning, for his welcome to the Northwest was exceptional. One of his first Indian meetings was with a very old Flathead chief, named Big Face. He was extremely grateful for Fr. DeSmet's presence, as he promised, "Black robe, we will follow the words of your mouth."91

DeSmet was very impressed with the eagerness displayed by the Flatheads for religious instruction. They immediately commenced praying together, at which time Big Face instructed the other Flatheads to listen to the Black Robe's teachings and to open their heart to God. DeSmet was also moved by the singing of the Flatheads, which he described as occurring "in harmony which surprised me very much and which I thought admirable of Savages."92 During his initial stay with the Flatheads, DeSmet laid down many foundations which he planned on further developing once he returned with more

\footnotetext{
${ }^{90}$ William J. Davis, "Peter John DeSmet The Journey of 1840," Pacific Northwest Quarterly 35 (January 1944): 36-37.

${ }^{91}$ Chittenden and Richardson, Life, Letters and Travels of Father Jean-Pierre DeSmet 224.

92Ibid., 224-226
} 
Jesuit missionaries. He spoke out against "heathen" customs, traditions and habits such as gambling, polygamy, warfare and slothfulness. Other accomplishments during the visit included the baptism of over 600 Native Americans of the region, including two head chiefs of the Flathead tribe, and the establishment of regular Sunday mass. In his journal and letters his initial impression of the Flatheads was positive as he commented on their courtesy, good sense of humor, fighting skills and great sense of tribal patriotism. Upon his departure he was overjoyed to have made such a profound impact on the Flatheads and he was eager to return to continue these Christian transformations. 93

There is no doubt that DeSmet's arrival was a cause of great joy among the Flathead tribe, but there were other explanations for his exceptional, warm welcome that should be noted. In 1839, the Flatheads, who were influenced by the Catholic Iroquois, commenced praying on a regular basis. Also during this year the Flatheads and the Blackfeet went to battle on the Plains, at which time the Flatheads proved victorious, only losing one warrior, whereas the Blackfeet lost fifty. This was an extremely rare occurrence, for the Blackfeet were a numerous and fierce tribe. Further, during that same winter, the Flatheads went without hunger in the tribe. These rare happenings were attributed to the new and regular practice of the white man's religion within the tribe. 94 Disillusioned by what appeared to be coincidental, the Flatheads were overjoyed to have the Jesuits establish a Catholic mission among them.

Fr. DeSmet briefly returned to the United States to enlist more Jesuits to establish the mission in the Rocky Mountains. Fr. Gregory Mengarini, an Italian Jesuit, proved a

93Ibid., 320-331.

${ }^{94}$ Claude Schaeffer, "The First Jesuit Mission to the Flathead, 1840-1850: A Study in Culture Conflicts," Pacific Northwest Quarterly 28 (July 1937): 234. 
very likely candidate to serve as a foreign missionary, for when completing his vows to the Society of Jesus, living among the Native Americans was his personal request. $\mathrm{He}$ wrote to Rome requesting this appointment in December of 1839 :

I am certain of this desire, as I am of my entry in the Company, therefore, I request the foreign missions of York Paternity and if you should ask where, I would answer any place, but my heart has been, and always remains there, where the poor souls have no one to help them escape the hands of the devil, and where there is greatest hope, in fact to give both life and blood for love of Jesus our Captain 95

His wish was to work among an aboriginal culture, namely the North American Indians. Mengarini also appealed to DeSmet because he was gifted linguistically, and DeSmet needed someone to help him decipher the Salishan. DeSmet also discovered Father Nicholas Point, a French artist who was willing to travel West to establish St. Mary's mission, not only for the service it would provide the Lord, but also because it would give him ample opportunity to sketch the Indians, lifestyle and landscape of the region. Three brothers from the society were recruited to assist the establishment of the mission and assist in the instructions and other needed duties. Brother William Caessens was a carpenter by trade, while Joseph Specht was a blacksmith and plumber. Brother Huet's role in the mission is unclear, but without doubt these men were all essential in the construction of St. Mary's, the cultivation of the raw land, and the religious instruction of the Flatheads. They are rarely given the recognition they deserve, perhaps because they did not take their final vows. 96

When DeSmet and his new crew finally reached the Flathead camp in 1841, they were delighted to discover that the Flatheads had remained loyal to the Catholic faith. In

${ }^{95}$ Mengarini, Appendix A, 230.

96Taylor, "Flatheads trekked 800 miles..." The Hardin Tribune-Herald 5 
a letter to "Rev. and Dear Father Provincial" written in September of 1841, DeSmet described his welcome into the Flathead camp: "The tribe had the appearance of a flock crowding with eagerness around their shepherd. The mothers offered us their little children, and so moving was the scene that we could scarcely refrain from tears." 97 Once again it was Big Face, now christened Paul, who lead the Flatheads in this grandiose welcome. The tribe had many reasons to be excited and eager for the coming of the Black Robes. Their medicine was one attraction which was rumored to cure many diseases. Their religion was also renowned for bringing good fortune to each man and women if practiced regularly. A more concrete and tangible explanation for the Flatheads' great faith in the Jesuits was in response to an apparition of the Virgin Mary in the time between DeSmet's first and second arrival. Big Face claimed that Mary had been seen by one of the children, who then prophesied that a great church of God would be erected in the location where she laid. He was positive that this occurrence took place in the approximate location of where the mission church of St. Mary's was built, but he did not recall this fact until after the church was built, raising skepticism about the story. This story traveled far among the different tribes of the Inland Northwest and soon the mission was swamped with different tribes of the region gathering to touch, see and hear the Jesuits. 98 Among these tribes were the Coeur d'Alenes, Pend d'Orielles, Spokanes and Nez Perce, all desiring the Jesuits to establish missions among their tribes.

After the missionaries established a routine of prayer service, which occurred three times daily, and following the baptism of hundreds of Flatheads and other different tribes, the Jesuits commenced the abolishment of those specific traditional customs which

${ }^{97}$ Chittenden and Richardson, 304-305.

${ }^{98}$ Wilfred P. Schoenberg, Lesuits in Montana, 1840-1960 (Portland, Or.: Oregon Society of Jesuits Press, 1960), 14-15. 
were deemed unchristian by the Jesuits. Hunting was one of the major Flathead practices which the Jesuits wished to banish, for they found it savage and a deterrent to the Christian instruction. This activity was more than just a simple custom though, it was a way of life, and because of this importance it would prove very difficult for the Jesuits ever successfully to halt this practice. Father Mengarini believed the custom of hunting to be one of his greatest challenges at the Flathead camp. He referred to it as "the nomadic, vagabond life which they are forced to pursue as in times of past, adhering to those ancient ideas, causes them to remain in their savage state." Another difficulty with hunting was that while the men were out on the Plains, they were apt to adopt more sinful habits, and simultaneously disregard all of their missionary instruction. ${ }^{99}$ Initially, Fr. Nicholas Point accompanied the men on these hunts to prevent this frustrating occurrence. This also provided him with prime opportunities to sketch and paint the scenes he witnessed. In the winter of 1842, when Point first traveled with the Flatheads on their seasonal hunt, he was pleasantly surprised when the men asked to be informed of all Christian Feast days. Point wrote that it was their wish to continue religious instruction in the same manner as it would occur at St. Mary's. They were very devoted in their prayer services, which took place both in the evening and the morning. When mid-July arrived, the normal time for their summer hunt, they again requested Fr. Point's presence, in order that they would not be distracted. 100

Many baptisms, first communions and other Catholic sacraments were performed during these hunts. In the winter of 1842 , Point wrote that, "About sixty adults had been baptized during the hunt." He also includes that one of the catechumens' favorite aspects of this sacrament was receiving a new Christian name."101 After this summer hunt,

\footnotetext{
${ }^{99}$ Mengarini, 207-208.

${ }^{100}$ Point, 147-163.

101 Ibid., 159-163.
} 
though Father Point discontinued accompanying the Flatheads on their hunting trips, possibly due to the danger involved, leaving the Jesuit missionaries once again to face their initial fear of losing their religious instruction to the corruption of the hunt.

Another traditional Native American practice which was unacceptable to the Jesuit missionaries was the warrior role of the men in the tribe. Fr. Mengarini felt that more than anything, the constant raids provided a barrier to the Flathead Christian instruction. Not only was this an offensive event, but also the Flathead warriors were expected to take defensive posts outside the camp to look out for possible Blackfoot raids. He explained the frustration of watching the young boys at age five and six emerging from their home in the mornings with a bow and arrow in hand prepared to spend the remainder of the day hunting and playing with the other boys. This left very little time for instruction, which upset Mengarini, for it was his opinion that this was the optimum time in a youth's life to receive Christian indoctrination. 102 DeSmet also shared the opinion that fighting simply to improve their status in the tribe was unacceptable. He spent much time instructing the Flatheads against this practice, teaching them it was against the word of God to practice evil against one's neighbor. He felt by 1845 that he had been somewhat successful in this quest. On one occasion he prayed with both the Blackfeet and the Flatheads, after which he wrote a letter to Rome:

Oh! how touching a sight it was! What a consoling triumph for Religion, to see United under the cross these warriors, whose scars told of so many blood battles with each other; these warriors, who had never met save in mortal hatred, to drown in blood the hate and vengeance that they had sworn each other.

He declared that after their community prayer, the tribes shared "one heart and one soul." 103 What he failed to comprehend was that this bond, although encouraging and

${ }^{102}$ Mengarini, 212-214.

${ }^{103}$ Chittenden and Richardson, 1213. 
positive, was nothing more than temporary. It was very conceivable that the following day the Flathead tribe could be raided by the Blackfeet or the Flatheads could scalp a Blackfoot warrior without provocation.

There were many less significant Flathead practices which were abolished by the Jesuit missionaries. One of these was the practice of gambling, which was prevalent among the whole tribe. It was Roman Catholic opinion that this practice was evil and the work of the devil. Fr. DeSmet believed though that it would not be a problem to eliminate, for he wrote, not long after arriving in the Flathead camp, that "These games were unanimously abolished, as soon as I had explained to them that they were contrary to the commandment of God."104

Other practices which were eliminated were intentional starvation, public nudity, polygamy and cruel punishments. The women, although not taking part in the hunt, were fully responsible for the slain animals and the food preparation. This placed them in an advantageous position, which they used against the men in retaliation for physical abuse. They would refuse to feed the men, and this starvation could last for long stretches of time. The missionaries attempted to end this habit by requiring the men to halt female abuse and the women were to cease starving the men. Mengarini reported that the Flathead men were reasonable and ended the abuse, but the women continued their mistreatment. In accordance, he wrote, "The ancient custom of female despotism consequently still exists in its entirety." 105 Ironically, another occurrence took place where a very zealous chief named "little chief" reprimanded a women for not saying her 
prayers by physically abusing her with his cane. DeSmet's response to this wrongdoing was that this punishment was very effective, for she prayed daily from then on. 106

The Flatheads most often wore clothing that covered the majority of their bodies. It was not uncommon, though, for children in the warmer months of the year to run around and play in the nude. Fr. DeSmet recognized that this custom was not harmful, and was only practiced with innocent intentions, but, regardless, he wrote in his journal, "we are determined, however to abolish this custom as soon as we shall be able to do it," 107

Severe punishment was one of the final Flathead customs the Jesuits were determined to eliminate. The fur traders of the early nineteenth century were the first to view the horrific punishments, such as flogging, burning and scalping which were imposed on wrongdoers and enemies and they refused to trade with the tribe if these practices were continued. 108 The Jesuits continued teaching against this practice in hope that it would soon be completely eliminated from tribal lifestyle.

Polygamy was also discouraged strongly by the Jesuits. Although this custom was not practiced by the majority of the tribe, for it proved too costly, it served as a symbol of a man's monetary position in the tribe. Fr. DeSmet quickly denounced this practice and declared all Flathead marriages invalid until performed again under the Catholic church. He did not feel that the men had enough obligation to their women if

${ }^{106}$ Chittenden and Richardson, 324.

${ }^{107}$ Chittenden and Richardson, 322.

${ }^{108}$ Cox, 166 , 
they could easily marry another or rid themselves of the first wife, which was common among the region's tribes. 109 This type of transformation was extremely difficult though, for attached to Flathead marriages were great ceremonies, such as the Prayer Dance and the Marriage Song, which celebrated the coming together of the couple in Flathead tradition, and these were also discouraged by the Catholic missionaries. ${ }^{110}$

While many aboriginal customs were being abolished, several white civilized traditions were being implemented. The first item to be addressed was the construction of the mission of St. Mary's, the first Catholic church in the Pacific Northwest. The first mission was erected in 1841 on the feast of the Assumption, hence the name. 111 The Jesuits commenced building almost immediately after the arrival. Mengarini wrote, "The earth was already frozen and the trench for the foundations had to be cut with axes. Trees had to be felled and trimmed in the neighboring forest and hauled to the place destined for the building." The walls of the chapel and house were made of logs and the gaps were filled with clay. 112 In order to prevent the wind and frigid air from entering the buildings the walls were lined with animal skin, a skill adopted from the Flatheads. 113 It was difficult to persuade the men of the tribe to assist in the building of the chapel and house, but Mengarini was somewhat successful after quoting Genesis, "you will earn your bread by the sweat of your brow." Following this he stated: "They began then, at least the chiefs to put their hands to work."114 By St. Martin's Day, the first Sunday of October, the unrefined chapel and house were finished. 115 The chapel was reconstructed

${ }^{109}$ Chittenden and Richardson, 332.

${ }^{110}$ Schaeffer, "The First Jesuit Mission," 245.

111Point, 37-40.

${ }^{112}$ Schoenburg, Paths to the Pacific Northwest, 22

${ }^{113}$ Mengarini, 224-225.

${ }^{114}$ Ibid., 77.

${ }^{115}$ Ibid., 63. 
and improved later under the instruction of Fr. Anthony Ravalli. He arrived at the mission in 1845 and by 1848 Mengarini wrote that he and Ravalli had formulated a plan for a Flathead village: "We have begun to build a finer, more spacious church, a house for the missionaries, and a permanent village for the savages. Since the enemy harassment does not allow the construction of homes in separate locations, the village is being built in this manner quadrangular shape of a fortress." He proceeds to explain that the houses were to be twenty square feet high and at least fifty feet apart. 116 Unfortunately the time spent creating these plans was wasted time, for the Jesuits would abandon the mission only a year later.

After the original construction was completed, Fr. DeSmet and the other Jesuit missionaries commenced the implementation of land cultivation in the tribe. It was not easy to find seeds to sow in this region; therefore, Fr. DeSmet and a group of Flatheads had to complete the three hundred mile journey to the trading post in Colville. There, they received seeds for wheat and vegetables, and by the spring of 1842 those seeds were planted and growing. 117 Farming was implemented at the mission for several reasons. The first is related to the Jesuits' dislike of the Flathead hunting tradition. They concluded that if the Flatheads were provided with food that was planted in their own tribe, they would have no reason to travel to the Plains to hunt bison. Secondly, Fr. DeSmet found that cultivation fit into his system of Christian conversion. This plan included "(1) the nurturing of a simple, firm faith; (2) a respect for authority; (3) industry and a love of labor; (4) flight from all contaminating influences of what the Gospel calls the world."118 The growing of crops and vegetables not only assisted in completing the

${ }^{116}$ Ibid., 225.

117Peter Ronan, Historical Sketch of the Flathead Nation (Minneapolis: Ross \& Haines Inc., 1965), 29.

118 Mengarini, 95. 
third step in this process, but also the fourth. It was the Jesuits' belief that working with the land and nature was the closest a man could come to working with God. It was the third step, though, which DeSmet in particular wished to implement among the Flatheads. He recognized their idleness and also believed that they placed too much of the workload on the women of the tribe, but he felt that through land cultivation the men could overcome this laziness which could only result in corrupt habits. ${ }^{119}$ Finally, it was the shared belief of all the missionaries that the transformation which occurred from a seed to a crop was a very valuable Christian analogy of the growth of new life. 120

When the Jesuits initially commenced the planting of the seeds, the Flatheads did not believe that it was possible for the small seeds to grow into a full plant in the manner that the Jesuits described. Their disbelief was so intense, they simply laughed when the Jesuits spoke of the future full-grown crops and vegetables. Some Flatheads were disturbed at the tearing up of their soil, yet as the plants grew and the food was produced in front of their eyes they were awed and excited to taste them. ${ }^{121}$ Vegetables grown included potatoes, corn and onions. The Flatheads were not pleased with the taste of all the vegetables, in particular onions, which they decided would be better food for the horses. 122 The Jesuits also grew a vegetable garden exclusively for themselves, which may have caused resentment among the Flatheads. The Flatheads' desire to hunt buffalo outweighed their interest in cultivation, though, and not long after the novelty dissolved, the tribesmen were once again on the Plains. It was not until Fr. Anthony Ravalli arrived with a set of buhrstones and constructed the first flour mill in the region, that the

${ }^{119}$ Chittenden and Richardson, 329.

${ }^{120}$ No Author, The Indian Sentinel 31 (October 1919): 14.

${ }^{121}$ Schaeffer, 110-145.

122Ibid., 235-236. 
Flatheads discovered the great advantage of agriculture. 123 The one major problem which resulted in the growing of crops was that the mission was the only location in the region to cultivate land and produce crops, and therefore it attracted not only other tribes that were hungry for food, but also groups of trappers who were hungry in the winter. The missionaries feared the influence that the trappers would have on the Flatheads, for they were infamous for their lack of morals and heavy drinking. 124

The most significant and obvious transformation which was made by the Jesuits in the Flathead tribe was the discouragement of the practice of any Native spirituality. The Flathead spirituality was so rapidly replaced by Catholicism that the Flatheads did not realize the extent of the impact this would have on their lives. The best example of this was the Flatheads' use of the shaman as a healer of illness in the tribe. DeSmet felt that these men and women who treated diseases were heathen, savage and persons to eliminate before the tribe could be considered civilized. ${ }^{125}$ It should be noted, though, that not all of the Jesuits shared this belief. One of the most admirable qualities in Father Ravalli's work was that he combined his own knowledge with that of the shamans and herbal doctors. He felt that many plants used in the herbal treatments were often successful, and he wished to acquire the skills which these men and women possessed. It also proved a necessity for him, for he only received two shipments of medicine in five and one-half years. 126 Previous to Ravalli's arrival in the Flathead region, he had worked among the Colville tribe for a short time. In this time he was forced to live without his

\section{1.}

${ }^{123}$ Hellen Addison Howard, “Versitile Missionary," Catholic Digest, (February 1940),

${ }^{124}$ Mengarini, 14-15.

${ }^{125}$ Chittenden and Richardson, 1213.

${ }^{126}$ Allen, Adrien, "Man Against Wilderness. The story of Father Ravalli," article in the hand of the Society of Jesus, The Pacific Northwest Tribes Missions Collections of the Oregon Province Archives of the Society of Jesus, Gonzaga University, Spokane, Wa. 
usual necessities of life and subsisted on dried buffalo meat, roots and berries, and perhaps after discovering that he could survive in the aboriginal world, sharing their customs, including diet, he granted more credit to the tribe's medical practices as well. 127

Other spiritual practices, besides shamanism were replaced as well with Roman Catholic procedures. The sun had been worshipped in the Flathead nation for countless generations and was expressed through dances such as the Prayer dance, which thanked the Sun and the Earth for providing the people of the nation with good health and an abundance of food. 128 The obvious belief of the Jesuit missionaries was that this gratitude should be directed to the Lord, for he provided the people with the Earth and the Sun, and the manner in which it should be expressed was in prayer and service to God. Adolf Hungry Wolf, an adopted relative of the Flathead nation who lived among the tribe at the turn of the century, described the general attitude of the Flathead nation best when explaining why the Jesuit missionaries failed. He wrote, "The people had wanted to add Catholicism to their own Ways of Life- not to exchange their Ways for the ways that the priests demanded."129

Only two years following the initial arrival of Fr. DeSmet at St. Mary's, he felt it was time to leave and establish another Catholic mission among the Coeur d'Alenes, neighbors to the Flatheads. He left in the spring of 1842 with a lay brother, but before doing so, he did secure three more Italian Jesuits who arrived in 1843 and worked in the various missions being established in the region. Of those, Fr. Zerbanatti situated himself at St. Mary's and Fr. Ravalli remained at the mission among the Colville tribe. Ravalli

${ }^{127}$ Ronan, Historical Sketch of the Flathead Nation, 33.

${ }^{128}$ Schaffer, 240.

${ }^{129}$ Adolf Hungry Wolf, Charlo's People The Flathead Tribe (Inermere, B.C., Canada: Good Medecine Books, 1974), 7. 
was not to remain long in this area, though, for in 1845 Zerbanatti drowned, leaving Mengarini alone among the Flatheads. Fr. DeSmet instructed Ravalli to depart from Colville and reestablish himself at St. Mary's. This was not an unpleasant transfer for Fr. Ravalli, for St. Mary's was where he originally desired to work. 130 Father Ravalli essentially replaced Fr. DeSmet as head missionary at St. Mary's. Although this is never documented and could be disputed, for Fr. Mengarini had lived among the Flatheads for a longer period of time, Ravalli was looked to first when problems arose among the Flatheads. It was believed that he was capable of completing any task. He had studied medicine under an accomplished doctor in Rome, as well as art, sculpture and carpentry. He brought the tools necessary for him to construct, with the help of the lay brothers, the first grist and saw mill in the region. He improved on the interior of the chapel adding sculptures and paintings. His relations with the Flatheads were as commendable as to be expected for the worsening situation. The first few years spent with the Flatheads were successful. The mission was prosperous with the crops and vegetables in full growth and the Flatheads remaining fairly content with the presence of the Jesuit missionaries among their tribe. ${ }^{131}$

It is difficult to pinpoint the precise time when the Flatheads changed their opinion of the Jesuit missionaries, but it can be approximated at about 1847. This, of course, is the same year as the Whitman massacre, as well as the height of the great migration over the Oregon trail. The Flatheads did not need the Jesuits any longer and found that they did not necessarily desire their religion either. They returned to many of their traditional habits, which were deemed heathen by the Jesuits. The Jesuits missionaries' lives became endangered not only by the Flatheads but by neighboring

${ }^{130}$ Ronan, 32-33.

131 Ibid, 30-33. 
tribes, such as the Blackfeet. In order to preserve their mental and physical health, they closed and abandoned the mission in 1849, and in 1850 it was sold to Major John Owen to be utilized as a trading post. 132

There are many theories as to why the Flatheads turned against the Jesuits after seven years of good relations, but there are five basic explanations which are accepted by regional historians. The first deals with DeSmet's numerous promises and the expectations of the tribe. Upon arrival, he made many promises to the Flatheads that he could not possibly fulfill. His intentions, although innocent and honorable, were unrealistic and resulted in the dissolution of the mission. He also lived among the tribe for only two years, which was most likely a shock to the older Flatheads who had initially welcomed and accepted him. He departed for another tribe, which left older chiefs and other members of the Flathead nation who had placed a great deal of faith in him disappointed and disillusioned.

The Blackfeet-Flathead wars was another explanation for the mission's ending. Ravalli placed full blame for the dissolution on the Blackfoot raids. In one of these raids, a Flathead boy was killed outside the Jesuit house. Ravalli surmised that this murder was intended for him 133 The Blackfeet raids not only endangered the Jesuits, but also during battles on the Plains, the Jesuits would remain at the camp with the women, children and elderly, without any protection.

${ }^{132}$ Schaeffer, 140-145.

${ }^{133}$ Anthony Ravalli, S.J., Montana to Lawrence B. Palladino, 8 December 1879, transcript in the hand of the Society of Jesus," The Pacific Northwest Tribes Missions Collection of the Oregon Province Archives of the Society of Jesus, Gonzaga University, Spokane, Wa. 
Another explanation that both Ravalli and Mengarini furnished was the passing away of the finest members of the nation, leaving individuals who believed their minds were being poisoned by the Jesuits. Palladino summed it up best in stating:

When they did not receive all they wanted, and when their immorality was rebuked, they took revenge by slandering the missionaries, especially $\mathrm{Fr}$. Mengarini, for the avowed purpose of poisoning the simple minds of the Indians against them and their work. 134

The final reason provided for St. Mary's termination is a more tangible explanation regarding the influence of the fur traders on some of the younger Flatheads. Fr. Ravalli wrote in a letter to L.B. Palladino, the author of Father Ravalli: Forty Years in the Rocky Mountains, that in the fall of 1848 there took place a great Mormon migration to Salt Lake City, which was not too far from the mission and Fort Hall. The FrenchCanadian trappers, many of whom were formerly engaged with the Hudson's Bay Company were extremely interested in reaching this group and selling them pelts. In their journey to Salt Lake City, the trappers took notice of the cultivated lands of St. Mary's, and concluded that as this was the only location in the region producing crops, it would be to their advantage to camp the winter months here. They spoke with Jesuits, claiming they desired religious instruction but it was well known that these men were morally corrupt and had no notions of the kind. Fr. Ravalli denied them hospitality at the mission with the claim that the missionaries had harvested only enough crops for themselves. Ravalli explained that this prompted the trappers to retaliate by speaking poorly of the Jesuits to the Flatheads. They led many of them to believe that the Jesuits were attempting to poison their minds, and that the Flatheads should not listen to anything they preached. They were somewhat successful in their rhetoric, for they spoke to the

${ }^{134}$ Lawrence B. Palladino, S.J., Anthony Ravalli. S.J. Forty Years a Missionary in the Rocky Mountains Memoirs (Helena: Geo E. Boos \& Co. Printers, 1884), 116. 116. 
Flatheads in the Salishan tongue, which they had acquired knowledge of through their many years of relations with the Salish family tribes. Their success was proven the following spring when they left for Salt Lake City and persuaded many of the Flathead men to join them, leaving the Jesuit missionaries once again with the women and children. 135

The Jesuit missionaries were then left entirely vulnerable to attacking tribes in a period when White-Indian relations were not at their best due to the Whitman massacre and the migration of whites into the Pacific Northwest. It was the consensus that they could not assist the Flathead tribe anymore in their religious instruction without endangering their lives; therefore, the mission was closed. Following the abandonment, the Jesuit missionaries were transferred to safer posts along the west coast.

${ }^{135}$ Ravalli, A letter to Palladino, 11-12. 


\section{Chapter V}

\section{The Whitmans with the Cayuse Tribe}

Dr. Marcus and Narcissa Whitman, in the company of Eliza and Henry Spalding crossed the continent and arrived in the Pacific Northwest in September of 1836. The Whitmans made their home among the Cayuse at the Wailaptu station and the Spaldings moved on to work among the Nez. Perce at the Lapwaii station. Much tension had developed between the two couples because of Henry Harmon's jealousy for Marcus and Narcissa's marriage. Due to this situation it was decided that two Protestant missions would be established in the Pacific Northwest. Narcissa Whitman commented in her journal, "After consideration it was concluded best to for several reasons. The Cayuse as well as the Nez Perces are very anxious to have teachers among them." 136 It was most likely somewhat of a relief when the Spaldings departed for their own station, for both couples were enthusiastic about commencing their education of the natives.

The Whitmans arrived at Fort Vancouver on September 12, 1836, and were very pleased to find themselves in a civilized location for the first time in three months. It was suggested that both Eliza and Narcissa spend the next month at Fort Vancouver, while their husbands were building their homes. It is evident that Narcissa very much enjoyed her visit at $\mathrm{Ft}$. Vancouver. She was provided with all of the basic domestic comforts. She had plenty to eat and found herself in the good company of the McLoughlins. She and Eliza were both asked to instruct in the Indian school, which they did. Narcissa went to meet Marcus at the new site of their mission in early November, but did not remain long for it was decided that it would be best if she returned to Fort Vancouver for a few more

${ }^{136}$ Drury, First White Women, 104-105. 
weeks. The house was not quite finished and Narcissa, being pregnant, was advised to wait until it would be more comfortable. Finally, in early December, Marcus brought Narcissa to her new home at Wailaptu. She was delighted to be reunited with her husband and this combined with her pregnancy, shed a cheerful light on the Whitmans first months spent at the mission. 137

Narcissa, upon first viewing her home, was overcome with joy. It was still very rude in appearance, however, and the Whitmans would spend the next few months working to improve their living conditions. They did this by building partitions so as to make different rooms in the house. They built a fireplace, and acquired tables and chairs from friends in the region. On February 18, 1837, Narcissa wrote home boasting of her new home and its contents, "We have now 3 chairs \& a bedstead \& all our doors are made \& hanging." 138 They continued to work at their new home in order to make it a more comfortable and livable place. The house was domesticated with a pet dog and cat, which were gifts from their friends, the Pambruns, another family in the region. 139 The Whitmans' new home was elaborate for their location, and one could suggest that possibly too much emphasis was placed on creating a comfortable habitation, instead of commencing the Christianization and education of the Cayuse.

It is difficult to determine whether Dr. Marcus Whitman had been spending time with the Cayuse in the first few months at the mission. He had met with them earlier during the Rendezvous and they assisted him somewhat with the building of his home, but prayer service and education of the Christian faith does not appear to have commenced until 1837. Narcissa, it is known, did not reach the Cayuse village until

${ }^{137}$ Jeffrey, Converting the West, 90-105.

${ }^{138}$ Drury, Marcus and Narcissa, 230-234.

${ }^{139}$ Ibid., 235. 
January 2,1837 . Why she waited this long to meet with the Cayuse is debatable. It may have been due to her pregnancy or possibly poor weather conditions, but it may have also be because she feared the Cayuse and their reaction to her. ${ }^{140}$ Although this was the most normal reaction from Americans during this period, it has been suggested by many regional historians that Narcissa Whitman's initial response to the Native Americans was not what one would expect to discover in a Christian missionary. Her first comments on the Cayuse written in her journal were of disgust. She wrote in January of 1837 of one of the Cayuse chiefs, named Umtippe who had made it clear that the land they had settled on was his land. She summarized her feelings towards him and to Indians in general when she wrote that he "has been a savage creature in his day. His heart is still the same, full of all manner of hypocracy deceit and guile. He is a mortal beggar as all Indians are."141

Her attitude, though, differed greatly when she was singing with the Cayuse people. She very much loved to sing, and was renown for her beautiful voice. The Cayuse, having leamed a few Christian hymns from the Hudson's Bay Company men, very much enjoyed singing with her and Dr. Whitman. She was very proud to have taught her husband the art of singing and wrote home to her mother boasting of this great accomplishment. However, she soon decided that due to her pregnant condition she could no longer participate in the evening chorus, for she felt it placed too much strain on her. 142 In February she again described the Cayuse in an extended missive to her mother. She commented that the congregation which took place in their home was continually growing in number. Only at this point did women and girls as well as men and boys desire to join the religious gatherings. She felt that the house was too small for the number of Cayuse who desired to participate, and she longed for her lost privacy.

${ }^{140} \mathrm{Jeffrey}$, Converting the West, 107.

${ }^{141}$ Drury, First White Women, 123.

${ }^{142}$ Ibid., 124-125. 
Marcus Whitman encouraged the Cayuse men to construct their own house of worship where they could gather daily and on the Sabbath, but the Cayuse would only accept the Bible classes and congregations in the Whitman home. Their concept of privacy differed greatly from the Protestant missionaries. They did not fully comprehend this considerable need for privacy and it was not long before many Cayuse considered the Whitmans to be haughty and proud. 143

Narcissa Whitman's initial opinion of the Cayuse tribe was much more evident in her letters and journal than was her husband's. He did not keep a written journal, therefore the only descriptions of his outlook on the Cayuse are found in the letters he wrote to David Greene of the A.B.C.F.M.. In these letters it is apparent that he did not want to leave the Board with the impression that the Cayuse were in any way discontent with the Whtiman's presence, hence his missives in these first years contain very few negative remarks about the tribe. His understanding of the tribes of this region appeared to have been very limited. His first descriptions of them are of his astonishment at their inadequate diet and their lack of proper hygiene. He wrote in a letter to Greene on April 21,1838 , "we find the natives of this country poor in the extreme, depending entirely upon roots, fish \& game for subsistence." 144 He was in awe of their diminishing number of people due not to disease but to poor nourishment, and he felt that it was more important in these first years to instruct the Cayuse people on white civilization rather than the gospel of the Lord. Spalding also shared this view. They wrote in a joint letter, "we believe it to be equally our duty to point with the other to the hoe; as the means of saving their famishing bodies from an untimely grave." 145 Marcus Whitman admitted that very few Cayuse lived near the mission the first winter, but when spring came about

144 A.B.C.F.M, vol., 138, vol. 1, 14.

${ }^{145}$ Ibid. 
they were eager to watch and assist in the cultivation of the land. 146 In the initial years at Wailaptu, one could conclude that Dr. Whitman was very frustrated with his position in the mission. He desired simultaneously to cultivate new lands and to convert the Cayuse to Christianity, but with Narcissa Whitman, who was unable to assist in the fields, he found himself continually falling short of his duties. In these first years, his letters to the A.B.C.F.M. shared the similar theme of the need for more hands and supplies at the mission. The other barrier in attempting to convert the Cayuse was their perplexing language, which neither Marcus or Narcissa could master in the beginning.

It is always difficult to determine the Native American reaction to foreign newcomers on their land, for such scant amount of information about it is recorded. The Cayuse requested the presence of the missionaries among their tribe, but whether they were aware of what they were requesting is doubtful. In the first six months of the Whitmans' occupancy, Dr. Whitman wrote of the initial reactions of the Cayuse. They were very intent on trading with the white immigrants in the beginning, not truly realizing that the Whitmans, as missionaries had nothing to trade. The Cayuse insisted, though, that they must have something to trade and it was the general feeling among the tribe that the missionaries were holding back. These notions were most likely derived from the fact that the only whites they had dealt with previously were traders of some kind. Their only method of dealing with white people was through trade, and in fact when the Whitmans requested that the Cayuse instruct them in their language, a price was set by the tribesmen, something unfathomable to the Whitmans. 147

146 A.B.C.F.M., vol. 138, vol. 2, 600 .

147 Ibid., 601. 
Timing proved excellent for the birth of the Whitman's first and only natural child, Alice Clarissa Whitman, on March 14, 1837. Dr. Whitman had commenced the harvesting of the vegetables and was busy in the fields most days. Narcissa was consumed with the care of her child and this period could be considered the happiest time of her stay. She spoke of the beautiful weather and wrote of the hospitality of the Cayuse on the occasion of the birth. A friendly Cayuse, named Tee-low-kike witnessed the new born child and called her a "Cayuse Te-mi," meaning Cayuse girl because she was born on Cayuse land. Narcissa appeared to have no problem with this title as she commented, "The whole tribe are highly pleased because we allow her to be called a Cayuse girl." 148 The delivery proceeded smoothly, despite the fact that Marcus had only days before bled Narcissa for a rash she had contracted. Unlike New York, however, there was not any female companionship during this critical time. This was something Narcissa greatly desired. Catherine Pambrun, a friend of Narcissa's from Fort Walla Walla, traveled to Wailaptu with her two daughters to stay with Narcissa while she convalesced, but not being well herself, it was Marcus who became the physician, nurse, cook and laundress during this time. 149 Alice became Narcissa's closest companion during the next two years. She was nursed for over twenty months and slept with Narcissa every night. Narcissa, like most mothers could see no wrong in her child, and used her as a standard to measure the Cayuse children by. She felt that Alice was more active, intelligent and inquisitive. 150

Again it is difficult to determine Marcus Whitman's general attitude concerning the Cayuse in these first years. He was very busy in the spring of 1837 planting different vegetables and when he wrote to David Green, the secretary of the A.B.C.F.M., he was

${ }^{148}$ Drury, First White Women, 127.

${ }^{149}$ Jeffrey, 110

150 Ibid, 128. 
able to boast two acres of peas, nine acres of com, and various other vegetables. $151 \mathrm{He}$ desperately needed help with the planting of these vegetables, but the Cayuse were unfamiliar with the process of cultivation. They did show some interest in farming however, and by the end of the first spring at Wailaptu Marcus Whitman believed that if they were to have the tools to cultivate, they would halt the tribes' wandering habits. 152 Narcissa disagreed with her husband when she later remarked on the Cayuse work ethic: "The Indians do not love to work well enough for us to place any dependence on them." 153 To make sense of these conflicting opinions, it has been theorized that some of the Cayuse did take to farming and others considered this type of work below them or work of their women. 154 Fortunately, Marcus attained two Hawaiians brought over by the Hudson's Bay Company as laborers, to help him during the spring harvest. 155 Although Dr. Whitman was not a minister, he was at this time conducting services and leading Bible classes. He felt that as a physician his practice was limited only to other missionaries. The medical work he did complete among the Cayuse was usually very difficult and stressful, for he was expected to perform miracles. As early as 1837 there was conflict with the Cayuse when Dr. Whitman was treating a very sick women. Her husband threatened to murder Marcus if she failed to survive his remedies. Fortunately for Dr. Whitman she survived. That spring was an exceptionally diseased season with inflamed lungs being the most common illness. ${ }^{156}$ He was very discouraged with the amount of time which he had to spend in manual labor. He complained many times to the

${ }^{151}$ Drury, First White Women, 131.

${ }^{152}$ A.B.C.E.M., vol. 138, vol. 2, 602 .

${ }^{153}$ T.C. Elliot, "The Coming of the White Women, 1836," Oregon Historical Quarterly 38 (March 1937): 57.

154 Jeffrey, 128-132.

155 Ibid., 131.

${ }^{156}$ Elliot, "The Coming of the White Women," 58-59. 
Rev. Greene that he was not able to fulfill the religious aspect of the mission, for all of his time was consumed in the fields. 157

It became increasingly frustrating for the Whitmans as they realized that the conversion of the Cayuse was not to be as simple as they originally anticipated. They did not expect the Cayuse to resist full acceptance of Christianity which they did, nor were the Cayuse prepared for the ritualistic mannerisms of the Protestant missionaries. By the second summer, the Whitmans' conversions were limited to a few Cayuse, the Hawaiian laborers, a visiting Scottish man and a French Canadian Catholic. 158 They had, however, commenced the beginning of a school for the younger members of the tribe in the winter of 1838 . There were regularly fifteen to twenty students in class learning to read and write the English language. The books utilized for these classes were provided by the Methodist Missionary of the Willamette Valley. Whitman wrote of his attempt to instruct the Cayuse people about the Ten Commandments and his frustration which followed, when he concluded: "They say they do not worship Idols but still I think many of their traditions are evidences of Idolitous worship of some Animals \& Birds." 159

Although the Whitmans did not consider the Christian conversion element of the mission to be successful at this time, they were content with their instruction of the Cayuse in civilization and cultivation. Whitman wrote to Greene in March of 1838 that the mission contained "six acres of potatoes $\&$ half of wheat and peas oats $\&$ corn enough to make forty acres probably." He requested a fair number of hoes, in order that every

${ }^{157}$ Jeffrey, Converting the West 132.

${ }^{158}$ Ibid., 127.

${ }^{159}$ A.B.C.F.M. vol. 138 , vol. $2,608-610$. 
Cayuse farmer may have his own hoe, for it was his opinion that without allowing the men to cultivate the land it was possible they may not visit the mission. 160

Before the turn of the new decade the Whitmans had experienced many hardships which they were not expecting; many over and beyond the daily ones which accompanied a missionary's work in a native land. First the Whitmans were forced to build a new home of adobe, when the Walla Walla River flooded their home repeatedly in the years of 1837 and 1838. Without the extra manpower, though, it was impossible to start construction; therefore, they were forced to live in poor conditions until the spring of 1840 , when Asahel Munger, an independent missionary and carpenter assisted Whitman in the building of the house. 161

A second surprise was the arrival of the Walkers, Eellses and Grays in the fall of 1838. The many requests for missionary reinforcements in the Pacific Northwest were finally heard, and these couples were sent to the region to assist the established missionaries as well as build a new one. William $\mathrm{H}$. Gray, who had been assisting Spalding at his mission, decided to depart and spend time in the Flathead region, before returning back to the States to marry his fiancée. 162 The Whitmans first learned of the arrival of the missionaries only a few days before their coming. The three couples also picked up Cornelius Rodgers along the way, who, although not appointed by the A.B.C.F.M., was eager to join the missionaries. It was soon decided that the Grays would locate with the Spaldings at the Lapwaii mission, the Smiths would remain with the Whitmans at the Wailaptu mission and the Walkers and the Eellses would establish a Presbyterian mission among the Flatheads. In order to do this, though, they were

${ }^{160}$ Ibid., 615-617.

${ }^{161}$ Drury, First White Women, 136.

162 Jeffrey, 132. 
required to stay the winter with the Whitmans and Smiths at the Cayuse station. The quarters were very small and this was where the problems began. Shortly after the arrival of the new missionaries, Narcissa became agitated and uncomfortable with the lack of privacy and space in the house. She felt that the women were not assisting her in the household duties which had greatly expanded. Mary Walker claimed that Narcissa often wept openly and felt helpless, but agreed that the other women were not taking their share of the chores. By the end of the winter, Narcissa appeared to have had difficulties with almost every individual missionary. Asa Smith ate too much, Elkanah Walker chewed too much tobacco, the women did not complete their work and, if they did, it was not done correctly. $163 \mathrm{Dr}$. Whitman also had difficulties with certain members of the expanded household. He and Asa Smith could not seem to cooperate with one another until it reached the point in February of 1839 , when Smith requested to leave Wailaptu and build his own mission home. After an emergency meeting was called among the missionaries, it was decided that the Smiths would remain at the Wailaptu station and the Whitmans would move to another more central location 164 But in March of 1839, when the Eellses and Walkers departed, Narcissa was reluctant to move to the new adobe house that was being built for the Whitmans and, therefore, they remained at the Wailaptu station. This resulted in additional strain to the Whitman-Smith relationship.

The final misfortune which occurred before the turn of the decade took place in June of 1839. While Narcissa and Marcus were spending an afternoon leisurely reading in their home, little Alice informed them she was going down to the river to collect some water. A while later, Narcissa noticed she had not heard Alice's voice in some time and scurried down to the river to find her daughter drowned. This event crushed much of 
what was left of Narcissa's spirit. Her greatest comfort at the mission was gone forever, and she blamed herself for being negligent, something she had accused the Cayuse mothers of repeatedly. She grieved long over her daughter's tragic death and could not make sense of it even when attempting to find the Lord's hand in the event. 165 It affected the remainder of her stay at the mission, as she was never able to conceive children again and therefore, she commenced adopting children. Catherine Sager, one of the many Sager children who were adopted by the Whitmans remembered that Alice Clarissa was buried within sight of the back door, which pleased Narcissa very much. 166 It could be conjectured that the Narcissa never completely overcame the death of her daughter in her remaining years at Wailaptu.

The significant aspect of these unfortunate events in the late $1830 \mathrm{~s}$ is that they drew much of the attention of the Whitmans away from the Cayuse. During these years the Whitmans made very little progress with the Cayuse in converting or civilizing them. They were emotionally wrapped up in the events at hand and attempting to resolve them, which left very little time for the Cayuse.

The next five years at the mission should have been a time when the Whitmans had settled in to their new life and were starting to make progress among the Cayuse tribe in their goal to civilize and convert. This would not be the case, however, for although the Whitmans did appear to have an increasingly normal daily agenda, the reception from the Cayuse was not warm. Narcissa did manage to regularly instruct close to thirty students every day in 1840 and 1841 , but when attempting to teach the women of the tribe civilized skills she failed completely. She complained in a letter dated July 25,1842 ,

165 Ibid., 145.

${ }^{166}$ Catherine Sager, Elizabeth Sager, Matilda Sager, The Whitman Massacre of 1847, (Fairfield, Wa.: Ye Galleon Press, 1981), 20. 
that she had spent much time attempting to instruct the Cayuse women in spinning and weaving, but the women of the tribe felt that they were to good for this type of work. 167 In describing her missionary work she wrote, "There are no flowery beds of ease here." 168 .

Marcus Whitman found even more difficulties with the Cayuse than did Narcissa, for he was more open to criticism when working in the fields among the tribe. Joe Lewis, a mixed-blood Iroquois, spoke to the Cayuse, informing them that throughout the rest of the United States, property owners were paid for their land and therefore the tribe should demand pay by the Whitmans. Tiloukaikt, the successor to Chief Umtippe, subscribed to these words, and he and some of the members of his band trampled on to the Whitman corn field with a pack of horses. The Walla Walla Indians who were working for Whitman were ordered by him to halt the intrusion, but the Cayuse tribesmen counteracted the order by threatening the laborers with whipping sessions. There was a great deal of jealousy felt toward these laborers, for they received prized possessions for their work. Tiloukaikt demanded to be reimbursed for the land Whitman had taken from the tribe, land he had been raised on, but Whitman flatly refused. Whitman, refusing to be baited by this disturbance, informed the Cayuse raiders that their horses could stay as long as desired eating his crops and upon hearing this Tiloukaikt responded by striking Whitman twice. Once again Whitman refused to react to these actions, and soon the horses were driven away. 169.

This type of confrontation continued both with Tiloukaikt, as well as other tribesmen. Only a few days after the first event, Tiloukaikt attempted to bait Gray and

${ }^{167}$ Drury, First White Women, 157.

${ }^{168}$ Ibid.

${ }^{169}$ Drury, Marcus and Narcissa Whitman, 437-438. 
then Whitman into a fight. He demanded that Whitman to listen to him and when Whitman did not display proper attention, Tiloukaikt yanked both of Whitman's ears. Whitman allowed him to do so until Tiloukaikt was tired or frustrated with a lack of reaction. 170 Another time both he and Narcissa were threatened with an axe and a hammer in their own home. Whitman recalled the rest of the event:

After I took away the ax, he held to my collar $\&$ struck me with his fist on the mouth \& tore my clothes. Mrs. W. took the ax from me \& Mr. G. put both the ax \& hammer up stairs $\&$ we then sat down again. Sakiaph soon returned with a club and advanced upon me. As I arose to take hold of the club, I avoided the blow he was leveling at my head. For this I was much ridiculed by the Indians as fearing death. 171

A turn in events occurred in the fall of 1841 , when Elijah White, the newly appointed Indian Agent for Oregon, arrived at Wailaptu to deliver a letter from Greene ordering the Spalding mission closed. This letter also requested relocating the Whitmans. It also asked that the Grays and the Smiths return to the states but these two couples had already departed. 172 This was cause for an immediate missionary meeting, where it was concluded that the Spalding mission should remain open, for it was successful both in cultivation and with the conversion of the Nez Perce. It was decided at this time that $\mathrm{Dr}$. Marcus Whitman would make the journey East to speak with the A.B.C.F.M. of these matters. He departed for the East Coast in 1842 and spent time in both Washington D.C. and in Boston.

In Washington, he spoke with President Tyler relating to him the state of affairs in the Oregon Territory. Whitman felt it was a very suitable living location and a place that

${ }^{170}$ Ibid., 438-439.

171 Ibid., 440.

${ }^{172}$ Clifford Drury, More About the Whitmans, Four Hitherto Unpublished Letters of Marcus \&

Narcissa Whitman (Tacoma: Washington State Historical Society Press, 1979), 5. 5. 
should be considered seriously by prospective emigrants. He then moved on to Boston, where he was greeted in a very cool manner by the A.B.C.F.M., and strongly rebuked for his trip to Washington D.C.., which was conducted without their knowledge. $173 \mathrm{He}$ spoke with the Board concerning the Spalding mission and was able to persuade them to keep the mission open. Upon meeting with the A.B.C.F.M. Whitman made two requests. The first was for an additional preacher to be sent to Wailaptu and the second was for five to ten Christian men to be sent to the Oregon country. He concluded that these requests would result in the settlement of fine, pious white men who could positively influence the Indians. Their presence would counteract the Roman Catholic influence in the region. It would relieve the missionaries the stress of the large amount of labor and allow them to devote their time to true missionary work. It would encourage other Christian families to come west and settle in the Northwest and "it would save the mission from the necessity of trading with immigrants. Those now enter the country expect to purchase or beg their supplies from the mission. . ."174

Marcus Whitman did not return empty handed. In fact, he returned to the Pacific Northwest in the fall of 1843 with over two hundred wagons. It has been debated whether he was actually responsible for this great migration. He has also been dubbed the man who saved Oregon from foreign control, but most historians have concluded that he was not singularly responsible for either of these events. He did, however, greatly assist the wagon train of 1843 by administering medicine and advice. Gray recalls spotting Whitman on "the 5th of September, 1843 saw the rear of the Doctor's caravan of nearly

${ }^{173}$ William H. Gray, The History of Old Oregon, 1792-1849 Drawn from Personal Observation and Authentic Information (Portland: Harris \& Holman, 1870), 316-317.

${ }^{174}$ A.B.C.F.M, vol. 248 , vol. $1,355$. 
two hundred wagons, with which he started from Missouri last April, emerge from the western shades of the Blue Mountains." 175

The Cayuse rejection of the missionaries became stronger directly following the migration of 1843. Although the Whitmans had experienced many difficulties with the Cayuse before this journey, it was not until after the return of Whitman and the arrival of white pioneers that the Cayuse suspicions of Whitman's intentions greatly increased. Marcus Whitman's hope for the conversion of the Cayuse had withered away almost completely by this time. He wrote to the Rev. Greene that the only time he saw the Cayuse was during the spring when cultivation commenced. After six years of attempting to curb their heathen habits he became frustrated and wrote, "the superstition of the supernatural agencies of Magick, Charm \& Sorcery are universal \& by no means easily eradicated." 176 In November of 1843 , Whitman witnessed a brutal murder among the Indians which lead him to believe that it would be an impossible feat to rid the Indians' mind of sorcery and evil. 177

With the migration of the pioneers, the Whitmans strongly hoped for a decrease in their amount of manual labor. This would allow the Whitmans more time to instruct the Cayuse religiously. This prediction did not to occur for two reasons. First it was Whitman's opinion that the white pioneers who were relocating in the Pacific Northwest were not the type of people he deemed appropriate for assistance in the conversion of the Cayuse, for he felt they were not particularly religious. 178 Second, with the everincreasing white migration, the Whitmans were forced to spend more time with the

${ }^{175} \mathrm{Gray}$, History of Oregon, 290.

${ }^{176}$ A.B.C.F.M. vol. 138, vol. 1, 705-708.

${ }^{177}$ Ibid., vol. 138, vol. 3, 732 .

178 Ibid., 714. 
pioneers. Their station was the first civilized stop in the Pacific Northwest which resulted in many needy and sick pioneers requesting the aid of the Whitmans. It also became a common place to winter, if a party were delayed and could not reach their destination before the season ended.

Although this could be considered the beginning of the demise of the Whitman mission, one would never recognize this fact in Narcissa's disposition. She very much enjoyed having the company of white pioneers. It brought her closer to the home she had left in 1836. In 1844, the Whitmans accepted the seven orphaned children of the Sager family, with ages ranging from fourteen years to five months. ${ }^{179}$ Catherine Sager remembers the house being continually filled with company and "Mrs. Whitman having no help was too much engaged in household affairs to pay any attention to us." 180 By this period, Narcissa had all but given up completely on any work with the Cayuse. She cared very much for her children, especially the youngest Sager who was but an infant. She was also busy with the guests, providing them with food and a place to sleep. Laura A. Patterson Hawn, a pioneer, recalls the Whitmans providing them with "wheat that had been grounded on the mill. meat and potatoes." She remarked that they remained with the Whitmans for four days until ready to move on. ${ }^{181}$ Narcissa also managed during this period to develop her flower garden. Catherine Sager remembers that "she was passionately fond of flowers and a portion of her time was spent every season in cultivating a flower garden." 182

${ }^{179}$ Drury, Eirst White Women, 151-152.

${ }^{180}$ Sager, The Whitman Massacre, 22.

${ }^{181}$ Laura A. Patterson Hawn, "Reminiscences of 1843 Travels to Oregon," [typescript], p. 5-6, Mss. \#381, Special Collections, Oregon Historical Society Library, Portland, Or.

${ }^{182}$ Sager, 25. 
Suspicion deepened among the Cayuse as to the true intentions of the Whitmans. Tom Hill, a mixed-blood, had a profound effect on the Cayuse. He was an eloquent speaker who even impressed Whitman with his orations. 183 He warned the Cayuse, though, of the increasing number of whites who would soon be entering their land, a notion that frightened the Natives more than anything else. They suspected the Whitmans of purposely not instructing them in the English language, in order that they would not be able to trade with white immigrants when they came west. 184 They witnessed how much time was spent assisting the passing immigrants and it frightened them greatly, for it was one of their beliefs that if the whites were to take up arms against the Native Americans of the region, the Whitmans would immediately ally themselves with them. 185

The other fears that excited the Cayuse greatly was their suspicion that the Whitmans planned to annihilate the members of the tribe by poisoning their food or water. Again, these type of suspicions needed a powerful instigator. In this case it was another mixed-blood, Joe Lewis, who came to Wailaptu in 1847. Being sick upon arrival, Whitman allowed him to remain at the mission. In addition to supplying him with necessities, such as food and clothing, Dr. Whitman took him in and employed him for the winter. He apparently was a worthless character, for not long after he arrived at Wailaptu Whitman warned in a letter to a nearby missionary, "never to employ Wisin [Lewis] again if it can be avoided." He refers to him as a "worthless vagabond, not worth the food he eats." 186 Soon after his arrival at the Whitman station he commenced stirring up agitation among the Cayuse. Spalding recalls him telling the Indians that he and Dr.

\footnotetext{
${ }^{183}$ Ibid., 34-35.

${ }^{184}$ A.B.C.F.M, vol. 138, vol. 3, 726.

185 Ibid., vol. 248, vol. 1, 269.

186 Drury, More About the Whitmans, 14-16.
} 
Whitman had been "consulting at night to the most effective method to kill off the Indians." 187 Many of the Cayuse believed this rhetoric, for it was provided for them at a time when they were extremely wary of the intentions of the white population in the region.

By this time, Whitman was beginning to show the strain of being a missionary in an increasingly unreceptive territory. He wrote to the A.B.C.F.M. in 1844 that Narcissa was very ill with Tympanities and he expected her death soon, and that he was also not well, suffering from a tumor on his instep. Because of his condition, he was bound to walk on a crutch. 188 What was more noticeable was his fear of a Roman Catholic takeover of the Pacific Northwest. He wrote repetitively to the Board warning them of the different missions sprouting up throughout the Northwest. He wrote as early as 1843 commenting on the moves of Fr. DeSmet through the region. He wrote to Greene that his purpose for warning the Board of the Jesuits' progress was because the Northwest was, "the only spot on the Pacific coast left where Protestants have a present hope of a foot hold It is a requisite that mor good pious men \& Minister go to Oregon without delay, as Citezens or our hope there is greatly clouded if not destroyed." 189 He also had been informed by a friend not to blame Tom Hill solely for the agitation of the Cayuse, but to beware of the Jesuits, for they were also starting false numors of poisoning. ${ }^{190}$ Later, only two months before his murder, Dr. Whitman would write a letter to Alonso Hinman at the Dalles warning him of the coming of the papists. He wrote, "I hope the Indians will be encouraged to regard the land on the lower plains as the place where they are to plant and not let the papists have it. I want much to see them before they give their leave

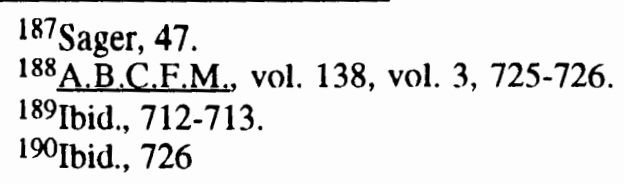


to the Papists for a station." 191 This competition to establish one religion exclusively in the Pacific Northwest region became easily noticeable to the Cayuse, and they used it to their advantage, threatening to give the Whitman station to the Jesuits and to leave the Protestants for the Roman Catholic faith. 192

It would appear that at this stage of events, the Whitmans would have considered departing from this country and moving on. They had endured more misfortunes in eleven years than most emigrants had encountered in a lifetime. One of the most unfortunate happenings was when the grist mill was burned to the ground. This event occurred during Marcus Whitman's absence in 1842. Narcissa Whitman informed her husband of the burning, "The mill was burnt about the fifteenth of Nov. the thrashing Mill and lumber that was about it was also consumed-As it was not discovered untill very late $\&$ the fire had made extensive progress but few efforts were made to extinguish it."193 This event more, than any other, symbolized the Cayuse rejection of the Protestant missionaries and everything they had brought to the region. The cultivation which was once enticing, was now ignored. The grist mill which supplied the Cayuse with much needed flour no longer existed. Most important, the Christian conversion which was intended to take place never would, for the novelty of this new religion had worn away and there was not much tribal interest in a religion which prohibited their hereditary customs. The Whitmans were clearly not wanted in this region. Catherine Sager remembers Tomahas, one of the more assertive Cayuse, plainly stating to Marcus Whitman, "to leave the country; that he did not want him there." 194 Dr. Whitman spoke with Mr. Rodgers, a pioneer they had taken in for the winter, of the many difficulties

${ }^{191}$ Drury, More About the Whitmans, 12-13.

${ }^{192}$ A.B.C.F.M. vol. 138, vol. 3, 705.

193 Ibid., 739.

${ }^{194}$ Sager, 36. 
with the Cayuse. He complained of "the discontent of the Indians, the Catholics coming in so thick and the insinuations of Jo Lewis." Whitman confided in Rodgers that "If things do not clear up by spring, I will make arrangements and move my family to the valley. . "195 Perhaps, he was theorizing that, as in past spring seasons, the Cayuse would take an interest in the cultivation and therefore not act as intolerably, but Marcus Whitman would never see the spring of 1848 .

After all of these developments, the final events of November of 1847 should not have come as a surprise to those aware of the situation. The murder of Marcus and Narcissa Whitman, as well as twelve other whites, occurred on November 29,1847 . As the Whitmans and their guests were tending to their chores in the afternoon hours, a boisterous group of Cayuse were discovered in the kitchen demanding medicine from the doctor and milk from Narcissa. Marcus went to fetch the medication and went out into the kitchen advising Narcissa to latch the door behind him. 196 From the second room the rest of the crowd heard loud arguing followed by a gunshot. Narcissa cried, '"Oh! my husband is killed and I am left a widow,"' and wept over the disastrous situation. 197 After it quieted down, Mrs. Whitman went into the kitchen and dragged her husband's body into the sitting room, She treated the wound, but the bleeding would not stop. Catherine Sager discovered Mr. Rodgers running towards the house, with a gun wound at the waist and a tomahawk behind the ear. Narcissa, not knowing what course to take next, viewed the horrible scene outside the window and at that moment was shot through the right shoulder. 198 Tomsacky, a Cayuse, went upstairs to where everyone was hiding. He advised them to leave immediately for the house would be burned by nightfall.

${ }^{195}$ Ibid., 58.

${ }^{196}$ Drury, Marcus and Narcissa, vol. 2, 224-225.

197 Sager, 59.

${ }^{198}$ Ibid., 59-60. 
Narcissa, the Sager children, the Osbornes and the other visitors crept out only to discover a group of Cayuse prepared to finish what had been started. Narcissa was shot again and thrown in the mud. John, an employee at the mission, had been shot while attempting to protect Marcus Whitman. Mr. Saunders was killed in the retreat. Mr. Hoffman, who was butchering at the time, kept the murderers at bay with his ax until he could no longer fight, giving himself up to death as well. Mr. Marsh, James Young, Mr. Gilmore, Mr. Kimball and Francis Sager were all killed soon after. The Cayuse involved brought down the children, lined them up, preparing to kill them, when the Chief unexpectedly displayed mercy and halted the remainder of the massacre. 199 Catherine Sager recalled the women of the tribe being very good to the children. She wrote, "they made a great crying over us and gave us a great many things." 200

Forty-five people were kept captive after the massacre, but the ones directly related to the Whitman mission consisted of "Mr. Saunders and five kids; Mrs. Hall and five kids, Mrs. Hays and two children; Mrs. Kimball and five kids; Mr. Young and wife and two grown sons, Mary Ann Bridger, Eliza Spalding, Mary Marsh; four Sagers and Miss Beuly."201 Hall, Canfied and the Osborne family escaped captivity. Peter D. Hall decided that he would leave his family and attempt to reach the Dalles and inform somebody of the happenings. His body was never found, but it is believed that he was not killed by the Cayuse, but instead drowned in one of the river crossings. ${ }^{202}$ Canfield also escaped to warn Spalding of the occurrences at the Wailaptu mission in fear that it would also occur at Lapwaii. The Osborne family had a harrowing experience escaping

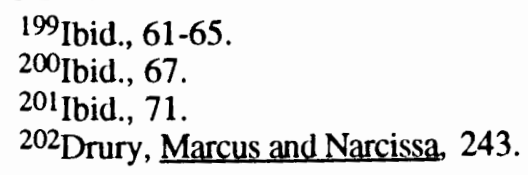


the Monday night of the massacre, with some of the children sick with the measles and Mrs. Osborne ill as well; they barely made it to safety. 203 The remainder of the captives were freed on December 29 through the efforts of the Hudson's Bay Company's Peter Skene Ogden, who negotiated the release of the prisoners for a load of supplies, including fifty blankets, shirts, tobacco and other items. ${ }^{204}$ In total, fourteen people were killed in the Whitman massacre, including Hall's drowning. Later three children died in captivity, due to the measles and other unknown causes. 205 One can speculate whether they would have died if they had been provided with medical attention from Dr. Whitman.

There are two categories of causes which resulted in the murders at Wailaptu. The first are long-term and the second are short-term. There are less obvious causes for the massacre which have been overlooked by historians in the past and these will be discussed in a later chapter. The long-term causes of the Whitman massacre and the dissolution of the Wailaptu mission are probably the most easy to detect.

First, the Whitmans, in coming to the Pacific Northwest, did not realize what type of response they were going to encounter. Narcissa, who had always found it easy to convert friends and family at home, discovered that her new pupils were not at all similar to those left behind and she found herself unable to relate to them. Marcus Whitman also attempted to treat the Cayuse as he would any non-Christian. He did not communicate with them in a comprehensible manner. After the murders, Jane Prentiss wrote to Rev. H.K.W. Perkins, a nearby missionary, inquiring the reasons why the Cayuse would wish to harm her sister and brother-in-law. Perkins responded frankly to her question, stating that the Whitmans were wrong for the job and that they were "out of their proper

\footnotetext{
${ }^{203}$ Ibid., 247-250.

${ }^{204} \mathrm{Jeffrey,} 220$.

${ }^{205}$ Drury, Marcus and Narcissa, 265.
} 
sphere." He continued by explaining that although he was feared, Dr. Whitman was not loved. He and Narcissa both lacked personal contact with the tribe. Dr. Whitman would not sit down and simply converse with the Indians. He added that Marcus Whitman "cared for no man under heaven."206 Of Narcissa Whitman, he commented,

That she felt a deep interest in the welfare of the natives, no one who was at all acquainted with her could doubt. But the affection was manifested under false views of Indian character. Her cairrage towards them was always considered haughty. It was the common remark among them that Mrs. Whitman was "very proud. 207

Perkins concludes that it was her misfortune and not her fault for being unadapted to the missionary lifestyle. 208 Marcus Whitman may also have misinterpreted the excitement the Cayuse displayed in the beginning. He believed that they desired the mission, in order to convert to Christianity, but it should have been evident that the Cayuse were not aware of what Christianity entailed.

This leads to the second explanation of the dissolution of the mission, which stemmed from the Cayuse perception of the Presbyterian missionaries. When Whitman first spoke with the Cayuse about settling among them, the idea was appealing to the tribe. Many of them had been practicing Roman Catholic type rituals which they had learned from the Hudson's Bay Company men, so they may have had a desire to learn more about religion. Also, they had heard that Marcus Whitman was a doctor, and were eager to observe his medical practices which were thought to be magic. Last, they were curious about the white people. There were still very few who had penetrated this region, and the few that had proved beneficial to the Cayuse through their trade. The arrival of these white missionaries thus was considered nothing but beneficial to the

206Drury, First White Women, 154-155

207Ibid.

${ }^{208}$ Ibid., 155. 
Cayuse. Soon, though, they realized that these whites did not come to trade but to convert the tribe to their religion. This was accepted by most of the Cayuse, but what was incomprehensible was that the tribe would soon be condemned for many of their normal practices and customs. In short, they would accept Christianity as they had done in the past, but they were not aware that adopting this religion under the Whitmans consisted of abolishing all tribal practices which were deemed heathen. This is what the Cayuse refused to submit to, and what resulted in a deep rooted resentment of the Whitmans.

By the same token, the Cayuse, although initially enthralled with the idea of cultivating their land, soon came to realize that farming was not necessarily what they wished to do with it. They had survived many generations using their traditional economy before the Whitmans' arrival. The Cayuse, after those first years, did not care to participate in farming; therefore, Marcus Whitman was forced to hire outside labor from the Walla Walla tribe.

One of the greatest long-term causes of the Whitman massacre was the increasing white population in the region. During the years of the Whitmans' stay at Wailaptu, the white population greatly increased as more families decided that the Columbia River basin was a desirable spot to settle in. This worried the Cayuse, as well as other neighboring tribes, for a number of reasons, but the two greatest among the Cayuse were the spread of disease throughout the tribe and the fear of losing their land. Although many of the wagon trains that journeyed across the continent were tainted with disease, it was not until the emigration of 1847 that the tribes were most affected by these illnesses.

Catherine Sager recalled the pioneers being greatly infected with whooping cough and the 
measles, and this frightened Dr. Whitman for he was aware of the devastating impact it would have on the tribe. 209 The natives of the region, unable to build up an immunity to these foreign diseases, were severely afflicted and a great number died. Unable to blame all of the pioneers, who immigrated that year, the Cayuse pinpointed the Whitmans.

Second, the most precious item to the Cayuse was their land and this was greatly threatened with the rising number of whites in the region. In 1843 , they refused to let Dr. Whitman break any more ground, believing that he would feed only the white population with the food produced 210 Some of the whites traveling through the territory informed them that they would soon have to buy land, as that was the way it was done in the rest of the United States. These threats were what terrified many Cayuse. There was a growing realization that they were losing one of their most cherished possessions.

The short-term explanations for the Whitman massacre all occurred in the final year before the murders. The first one centered around the arrival of the 1847 wagon train. Excluding the fact that they were plagued with white diseases, the Cayuse were extremely upset with the amount of time the Whitmans spent with the whites. As stated before, the Whitman station was the first civilized station in the Oregon country, and therefore many of the whites who were sick or in need of provisions stopped there for assistance, some spending the entire winter in residence. This infuriated many of the Cayuse who felt that the Whitmans' purpose was to work with them. An example of this occurred when two traveling men, Andrew Rodgers and I. Finley wintered the season of 1845 with the Whitmans They both were very well-liked by the Whitmans and received extra attention. This provoked jealousy among certain members of the Cayuse 
tribe, in particular Tamahas, who took revenge on the Whitmans by vandalizing the grinding mill. He would later be one of the ring leaders in the massacre. It simply added to the fear that the Cayuse were gradually being phased out of the region and that the white emigrants were taking their place.

An event as sudden and tragic as the Whitman massacre could not have taken place without a couple of ring leaders. In this case, the primary instigator in 1847 was Joe Lewis, a mixed-blood from the Iroquois tribe. Lewis took full advantage of the many Cayuse misfortunes and blamed them on the Whitmans. He spoke to the Cayuse in their own language, criticizing the Whitmans and explaining how they were to blame for the Cayuse poor luck. It is theorized that it was Lewis who started the rumors of Whitman's devious plot to poison the whole Cayuse tribe. 211 A similar situation occurred earlier with Tom Hill, another mixed-blood, who as a brilliant orator, warned the Cayuse of the grim future which was in store for them, yet, who was much more successful with the Nez Perce. Joe Lewis, though, was successful in rallying enough members of the tribe to commence the dissolution of the mission, through the murdering of its founders.

Besides these main short-term explanations, there were other minor ones that assisted in the final frustrations of the Cayuse with the whites. First the winter of 184647 was an extremely cold winter, resulting in the freezing of the mill, which Catherine Sager would describe, "no grinding could be done and we lived on boiled wheat and corn for several weeks." 212 This had a similar effect on the Cayuse, who were forced to live solely on what they had dried in the summer season, and it was Catherine Sager's belief that the Cayuse blamed the frigid winter on the arrival of white man. 213 Also there were 
other occurrences which instigated poor relations between the whites and the Native Americans in the region at this time. One of the happenings took place in the Dalles when a group of immigrants, believing their cargo was stolen by the Indians, intruded on the Native's ground and seized their goods, resulting in the death of one white man and one Indian. 214 These type of occurrences were becoming more frequent as the white population increased, adding more stress to the relations at the Wailaptu mission. The primary explanation for the Whitman massacre and the termination of the Whitman mission revolved around the Whitmans' lack of understanding and acceptance of the Cayuse and their traditions. 


\section{Chapter VI}

\section{The Spaldings and the Nez Perce}

The Spaldings arrived in the Pacific Northwest in September of 1836. While Eliza remained at Fort Vancouver with Narcissa Whitman, Henry Harmon Spalding, along with Dr. Marcus Whitman, searched for appropriate locations for their stations. In the beginning of October, the two men departed from Fort Walla Walla and by November 18, 1836, a location was found by the men for Marcus Whitman at Wailaptu. From this point the two men, along with a handful of Nez Perce guides, headed towards the Lapwaii valley, where there was rumored to be a location on the Clearwater River suitable for the second mission. This was found on the 29th of November. William Gray wrote that he and Spalding, "immediately arranged for building a house for him, which we commenced on the 3rd. of Dec. and succeeded in making it a comfortable winter quarters before I parted with him on the 28th." 215

Eliza, unlike Narcissa, was not as comforted by the small luxuries of Fort Vancouver and Walla Walla. She only wished to be by her husband's side while he was finishing the construction at Lapwaii. While the two waited at the Walla Walla station with the Pambrun family, they were encouraged to remain there, until the rest of the construction was completed, but Eliza would not hear of this, for she desired "the gloroius, blessed, but responsible work of laboring to introduce the blessing of that Gospel."216 She was extremely anxious to commence her work among the Nez Perce and 
this was evident by the simple fact that by January 27,1837 she had already opened a school for the Nez Perce. 217

According to the reports both Spaldings gave, the initial years of the mission were successful years. Henry Spalding's reports must be read with a careful eye, for he was later accused by most of his fellow missionaries in the Northwest of exaggerating his accomplishments. Asa Bowen Smith, who read of his accomplishments with the Nez Perce in the Missionary Herald, was so affected by these accounts that he accepted the appointment to work at the Lapwaii mission. Once there, he realized that all was not as successful as it was made to sound. 218 Henry Harmon Spalding's first journal entry was in November 1837. Approximately one year from the Spaldings' arrival in the Lapwaii valley, almost all aspects of the mission appeared to have been carried through with great success. Henry's letters to the A.B.C.F.M. and his entries in his journal record his accomplishments. On November 29, 1837, he wrote: "The Lord has blessed us with abundance of the fruits of the earth, about 2000 bushels of potatos, corn, wheat, peas \& c plent." 219 This was an amazing accomplishment for the first year in foreign soil. Spalding felt very confident in the work that was accomplished in those first years at Lapwaii, for he confided in Gray upon his departure that he had no doubt that soon he would have enough food grown to provide the whole tribe.

Henry Spalding, unlike Marcus Whitman, was fortunate in the first few years to have assistants to aid him in his daily duties, including William H. Gray, who was assigned by the A.B.C.F.M., but proved to be only temporary help and not very

217 Drury, Spalding and Smith, 236.

${ }^{218}$ Ibid., 106.

${ }^{219}$ Ibid., 248. 
dependable. He aided in the construction of the mission, but soon after departed at the end of December 1836. He left to explore the Flathead country to learn the customs and language of this tribe. 220 It was not long, though, before this task proved unsatisfactory to him as well, and he decided to return to the States. He was engaged, and it is theorized that he was eager to marry. Not surprisingly the A.B.C.F.M. were very upset with his lack of stability, and it is a wonder that they allowed him to return to the Columbia basin with his wife, Mary Gray. James Conner, a mountain man proved to be much more helpful during this period. He lived at the mission while they were still building and planting the first seeds. He was also a great aid to the Spaldings when it came to translation, for he was fluent in the Sahaptian language. Later, on December 10, 1838 he moved down the river, but having been converted, he visited the mission often, especially on the Sabbath. One Sabbath in particular he spoke in the Nez Perce dialect describing the wonders of his conversion to the tribe. Henry Spalding wrote on December 23, 1838, "Conner gives a brief history of his wicked life and concludes by saying he hates now what he loved once \& is determined to serve \& love no one but Jesus Christ."221

All of the Protestant missions in the Pacific Northwest were strongly criticized by the A.B.C.F.M. for spending too much time on the cultivation of the land and not enough on the teaching of the gospel, but the Spalding mission appeared to have borne the brunt of this protest. Although the Board mainly complained about the misdirected instruction, it was realized by all of the missionaries that the basis of these reprimands was the cost of the tools necessary for cultivation at the missions. Greene wrote multiple letters to Gray, Spalding and Whitman questioning their motives in placing so much emphasis on 
farming. Gray answered one of these accusing letters in a missive to Greene dated October 17, 1837. He wrote:

Do you ask me if we neglect the intellectual and moral cultivation of the Natives for farming, I answer not at all. We mean to connect the two and show the Natives the present benefits of Civilization in the partisipation of the means within their own obtaining. 222

He continues by explaining to Greene that the Nez Perce were ready to give up all of their heathen practices of hunting and accept the civilized method of cultivation. This would later prove to be a rash assumption, one which should not have been made after living with the Nez Perce for only one year. 223

Eliza Spalding also had great success in her teaching among the Nez Perce. She wrote in the spring of 1838 of the children's eagerness to learn the gospel. She expressed great interest in being able to instruct the children in their own language, but admits to not understanding the Nez Perce dialect. 224 Unlike Narcissa she enjoyed her time spent with the Nez Perce children and desired what she considered to be a better life for them. She wrote, "We hope to come to circumstances soon to do more to benefit the children for they are the hope of the nation." 225

Eliza Spalding's instruction was not exclusive to the Nez Perce children, for she spent many nights teaching the women the art of spinning and weaving in her home. 226 She was much more successful in this venture than Narcissa Whitman, the

${ }^{222}$ A.B.C.F.M. vol. 138 , vol. 3,761 .

223 Ibid.

${ }^{224}$ Drury, Eirst White Women, 200-203.

${ }^{225}$ Ibid., 203.

226I Ibid, 212-213. 
reason being that she did not require the same privacy that Narcissa did. She graciously welcomed the Nez Perce into her house and taught them as she would her own friends. Henry Spalding described the frequent occasions when the whole house would be filled with members of the tribe, often until the late hours of the night.227 All of Eliza's instruction was completed while in the late stages of pregnancy, for in the spring of 1837, Eliza Spalding, Jr. was born in Lapwaii, creating great joy among the Spaldings, as well as the Nez Perce.

Henry Spalding's duties in those first years were not confined solely to the instruction of cultivation, but they also encompassed the conduct of Sabbath services. Spalding's sermons were quite fervent, once causing a Nez Perce, Timothy, to cry out in grief. The Nez Perce were greatly interested in the sermons of Henry Spalding in the beginning, resulting in a large and faithful attendance. On the Sabbath of February 10, 1838, Spalding wrote that during and after his sermon their was a great amount of weeping and rejoicing. The missionary appeared to be so confident in his religious work that by January 1, 1839, he wrote in his journal, "Oh may there not be left at the end of this year one soul in this whole tribe to oppose God." 228

The Nez Perce reaction to the Spaldings was for the most part favorable in the beginning. They, like the Cayuse, were very interested in the cultivation of land. Whether it was due to their general attitude towards the missionaries or because of the Spaldings' work, they were also very accepting of other aspects of white culture which the Cayuse rejected. One example was the Nez Perce readiness to be instructed in the

${ }^{227}$ Eliza Spalding Warren, Memoirs of the West Spaldings (Portland, Or.: Marsh Printing Co., 1916), 74.

${ }^{228}$ Drury, Spalding and Smith, 250-251. 
classroom by Eliza Spalding. She wrote in her journal in their first year of residence at the mission that the Nez Perce "really appear eager to receive instruction." 229 One Nez Perce who was affected greatly by the arrival of the Spaldings was a man by the name of Timothy. He cared deeply for the Spalding family and was converted to the Christian faith. He had a special fondness for Eliza, for it was said that when he said his blessings he chanted "in the name of the father and the son and Mrs. Spalding."230 He was such a loyal convert and friend to Eliza that when they were forced to leave the mission following the Whitman massacre, he told her, "We shall meet no more in the schoolroom $\&$ my child will live only in a night that will have no morning." 231

In 1839 , the printing press arrived in Lapwaii. This extraordinary invention would assist in the printing of scripture in the Nez Perce language, therefore making it easier and speedier to learn. Spalding spent much of his time translating the Old and the New Testaments into Sahaptian dialect, for at this time there continued to be a genuine interest in Christianity. The press was obtained from missionaries who were working in the Hawaiian Islands, and was immediately put to use by Henry Harmon Spalding, who, when studying theology in the East, put himself through school by learning the trade of the printer press. This would prove extremely advantageous upon the machine's arrival. With the aid of Lawyer, a Nez Perce, Spalding successfully wrote seven books in the Nez Perce language. 232 When Joel Palmer traveled through the region in the early 1840 s, he visited the Spalding mission and wrote in his journal that he was extremely impressed with the quality of the scripture translations. 233

${ }^{229}$ Drury, First White Women, 200.

${ }^{230}$ Warren, Memoirs, 231-232.

${ }^{231}$ Drury, Eirst White Women. 231-232.

232 J.F Santee, "Lawyer of the Nez Perce," Pacific Northwest Quarterly 25 (January 1934): $39-40$.

233Palmer, 128. 
Also in 1839, the Spaldings welcomed the Smiths into their mission. They arrived at the Whitman mission in September of 1838 and remained there throughout the winter months. In the spring it was decided that they would move to the Lapwaii valley and assist the Spaldings at their established mission. Smith was surprised to discover that many of the accomplishments Spalding had written of in his letters to the A.B.C.F.M. were not completely true, and he also did not approve of the amount of time Henry Spalding spent in teaching agriculture. He expected to find the Nez Perce tribe strongly influenced by the gospel readings and lectures of the Spaldings. In a letter to Greene written in the summer of 1839 , Smith commented that he found it amusing that Spalding ever thought it conceivable for the Nez Perce to learn the English language before they acquired the Nez Perce tongue. He wrote "Not a child can be found who can read a single sentence of English intelligibly."234 Smith's expectations were unrealistic and therefore blame should not be placed solely on Spalding's exaggerations.

Beyond the initial miscommunications, there were personal difficulties between these two men. Asa Bowen Smith and Henry Spalding did not get along, for they both were very dominant in their manner. In fact, if one were to read through all of the diaries of the missionaries, it could be suggested that these two men were most likely the least cared for of all the missionaries. Almost each Presbyterian missionary had difficulties with Spalding or Smith at one time or another. Therefore, it did not come as a surprise that the two ran into personal conflicts. 235 By 1842 , Smith had already resigned. When the letter arrived in September of 1842, recalling Gray, Spalding and Smith, Smith had

${ }^{234}$ Drury, Spalding and Smith 106.

${ }^{235}$ Drury, First White Women Drury, Smith and Spalding, Drury, Marcus and Narcissa. 
already departed for the States and Gray was on his way back. 236 Spalding explains Smith's departure in a letter to D. Allen, on February 18,1842 . He wrote that both Smith and Rodgers were discouraged with the general attitude of the Nez Perce tribe and it was their feeling that the "savages" were incapable of becoming civilized or Christianlike 237

The peak of the Spaldings' work came in 1842 and 1843. Palmer, upon visiting the Spaldings, was astonished at their success. He remarked that many Nez Perce children were now able to read and write ${ }^{238}$ Henry Spalding, in a letter to Dr. Elijah White dated 1842, described some of his accomplishments. He asserted that the Nez Perce have now found increasing happiness in the cultivation of land in place of digging roots and fighting wars. He went on further to write, "the hoe soon brought hope, light and satisfaction, the fruits of which are yearly becoming much more than a substitute for their former precarious game and roots, and are much preferred by the people. . ."239 $\mathrm{He}$ estimated that in the previous season one hundred and forty members of the Nez Perce individually cultivated a piece of land ranging from a quarter of an acre to five acres. Regarding cattle, Spalding wrote, "Thirty two head of cattle are possessed by thirteen individuals." 240

Spalding also had almost nothing but favorable comments concerning the Nez Perce character, which apparently had much improved by this time. He remarked that although lying still remained prevalent throughout the tribe, stealing had diminished and

236, Drury, More About the Whitmans, 5.

${ }^{237}$ Warren, 80.

${ }^{238}$ Palmer, 128.

${ }^{239}$ Gray, 235.

240Ibid., 237. 
the act of polygamy was entirely abolished. 241 Their lessons were scripture readings and nothing other, for this was all they desired to learn and there was little else that interested them. 242 He commented that "very few are superstitiously attached to their medicine men who are without doubt sorcerers." The Native American custom of practicing medicine through shamans and other mystical powers was a sore spot with both Spalding and Whitman. They were both equally frustrated with the amount of trust placed in these men and women, for it was their belief that the native power was based on superstitions and did not hold any validity. 243 Whitman held that this practice of "sorcery" distracted the Native Americans from putting enough energy into the Lord's prayers. Spalding also added that the dances performed for the curing of the Nez Perce usually worsened their condition. He felt that because of this custom, which he soon hoped to abolish completely, the Nez Perce were taking his medicine for granted. 244

Spalding proceeded to explain that the mission had grown immensely since it was first established, currently containing "a dwelling-house, a schoolhouse, storehouse, flour and saw mills (all of a rough kind), fifteen acres of land under improvement, twenty-four head of cattle, thirty-six horses, sixty-seven sheep." 245 The school had also reached a high point in attendance, and with the press, Eliza and Henry Spalding were able to instruct the Nez Perce in their own language. 246 In the early 1840s, Dr. Elijah White's letter to the Secretary of War described his positive impression of the Spalding mission and encouraged Spalding to assist Whitman in creating a more stable and productive

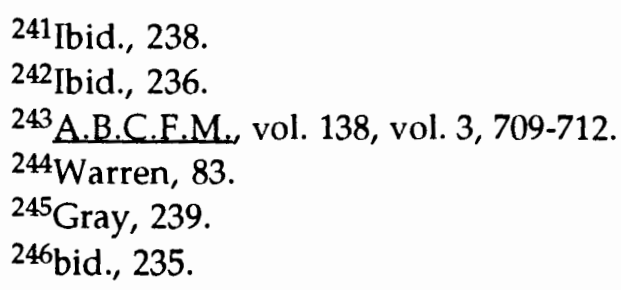


atmosphere at the Wailaptu mission. 247 Gray summed up the state of the Spalding mission in this period when he wrote that the Nez Perce and other Pacific Northwest tribes "as a whole of this report indicates are rapidly improving under the instruction of the missionaries in the interior." 248

Similar to the Jesuits among the Flatheads and the Whitmans among the Cayuse, the Spaldings experienced a sharp decline of Native interest in Christianity, cultivation or most anything identified with white civilization. Their suspicions increased through the years as they experienced more difficulty recalling the reasons for their initial desire for the missionaries' presence. They now viewed them as white intruders who wished to transform their daily customs and coerce them to behave in a white-civilized fashion. The Spaldings who observed minor examples of this behavior throughout their stay at Lapwaii assumed that these few, small problems would smooth out with the civilization of these people, but in the end, all that would be required was a few anti-white instigators and poor timing on the Spaldings' part to commence the final dissolution of the Lapwaii missionary.

Many changes occurred in the Lapwaii mission in 1842 and 1843. As the mission was seemingly reaching its peak of success, it was also beginning its decline. One of the most disappointing incidents for the Spaldings occurred on April 28, 1842 when a letter was delivered to Henry Spalding from his superiors at the A.B.C.F.M. recalling him and informing him of the termination of the Spalding station. Spalding was confused at first, for he did not realize that this missive had been delayed and was outdated upon its

247Ibid., 242-243.

${ }^{248}$ Ibid., 258. 
arrival. 249 Upon reading the letter he was very upset at the Board's initial decision to close the Lapwaii mission. He felt that it was the most successful mission in the Oregon country and could not comprehend their desire in terminating it. He wrote a long detailed letter to David Greene explaining his outlook on this matter and freely expressed his anger, frustration and embarrassment with this situation. In this letter he also wrote of his new found knowledge of certain missionaries who did not approve of his work with Nez Perce, finding it lacking Christian conversion. He found this very awkward, as he wrote:

Reports have been circulated in this country, that some of the members of this mission, were opposed to furnishing the natives with means for cultivating the soil, \& of collecting them into communities around the stations $\&$ c. - \& that myself would be called home for my feeble attempts to do so - - I have heard it more that hinted in some public meetings by some who were once members of the mission. 250

Even later, in 1845, Spalding wrote a letter to the board, in which he expressed continual anger and embarrassment for his recall. He noted that the fact must have become common knowledge among the Presbyterian community, for many of his friends and family were aware of the situation. As disturbing as this was for Henry Spalding he finished his letter by declaring, "I have no intention of letting this subject interfere with my work." 251

By 1845 almost all new aspects introduced to the Nez Perce by the missionaries had dissolved. The faith which was once held in the Spaldings had decreased rapidly with the increase of the white population in the region. Spalding wrote in 1845 of a great Native American fear of the incoming white's possible waging of war. It was the general

${ }^{249}$ A.B.C.E.M. vol. 248, vol. 1, 248.

250 Ibid., 256.

${ }^{251}$ A.B.C.F.M. vol. 248 , vol. $1,268$. 
belief that the missionaries would ally themselves with the white pioneers without hesitation. 252 He blames the new suspicious attitude on a couple of different events. First, with the coming of white pioneers, he felt that many were discouraging the Nez Perce from listening to the words of the missionaries and increasing their suspicions by alerting them of the white population who would soon fill the Pacific Northwest and buy up all of their land 253

Second, it was the belief of many of the Nez Perce that Spalding's instruction was evil for it was taught it the Nez Perce dialect. He complained, "They said they had been told by a prominent man of the immigrants that fall (/44) that our object in teaching them in their own language, was sinister, designed to prevent their intercourse with whites." 254 In addition it was the common belief among the Nez Perce that God only understood the English language. The members of the tribe also continually questioned Spalding about his medicine supply. He wrote that they believed he was not providing them with ample provisions of medicine, when in truth he did not have more to give away. 255 Other suspicions arose when more specific events occurred around the west coast. An example of this was when a Walla Walla Indian was killed at a trading post in Northern California. He had been at the Methodist school in the Willamette valley when he decided with a group of others to travel south to attain cattle and horses. While attempting to drive off extra horses, he was shot. He was traveling with some Cayuse and when they returned home, there was a debate whether to dispose of the Whitmans and/or Spaldings in retaliation for the white murder of this Indian. 256 This type of incident is what typically

252 Ibid., 269.

253Ibid., 270.

${ }^{254}$ lbid., 271.

255Ibid., 270-275.

256!lbid., 269. 
resulted in the negative opinion held by the Northwest tribes about the missionaries, for although they were not directly responsible, they symbolized the white takeover of the region.

These general suspicions resulted in direct retaliation by the Nez Perce. Through the years the Spaldings had experienced occasional minor incidents, but by the mid 1840 s they were a normal event. One of the more common methods of retaliating against the Spaldings was to destroy items that were introduced as necessities of white civilization. This included fences, mills and the burning of buildings. 257 In writing a letter to the A.B.C.F.M., Henry Spalding included an everyday occurrence for him at Lapwaii. He wrote:

... my tounge explaining the lesson to a class who come every morning. . but with my eyes I am observing a band of painted disorderly young fellows who are shutting down the safety gate at the mill dam which will cause the dam to fill $\&$ break somewhere doing great damage. 258

Another white introduction was the raising of cattle for meat. The Spaldings did very well in this department, increasing their number of cattle each year, and because it was successful and foreign to the Nez Perce before the missionaries arrived, it was a prime target. Spalding wrote in a letter to a friend, Dudley Allen of an account in which he bought a cow to increase his number at the mission and within a short time, he believed it was intentionally slaughtered by the Nez Perce. ${ }^{259}$ The threat to burn the Spalding house, school house or church was the most common occurrence and although it was rarely carried through with success, it was frightening nevertheless because it was all the Spaldings had.

${ }^{257}$ Drury, Eirst White Women, 227.

${ }^{258}$ A.B.C.E.M, vol. 248, vol. 1, 278.

${ }^{259}$ Warren, 74. 
More serious were the incidents that threatened the lives of the Spaldings. One such event occurred in the beginning of 1847. Eliza Spalding, who was teaching class in the schoolhouse was bewildered when she discovered two tribal members "naked \& painted with the most horrible figures \& continued their indecent jestures till Mrs. S. was obliged to leave the house." Eliza's departure so upset the Nez Perce that Henry reported five hundred of them threatening to tie her down and whip her ${ }^{260}$ Henry also confronted his share of troubles. Once when attempting to work the grist mill for the tribesmen, a group of Indians became agitated and refused to allow Spalding to continue, for they did not want a white man touching their food; and this resulted in a dispute between Henry Spalding and the unrelenting Nez Perce, with Spalding receiving the brunt of the fight. 261 Spalding documented in a letter to the A.B.C.F.M. another similar but more harrowing experience. He wrote:

I have had a gun cocked \& presented at my head for 15 or 20 minutes while 4 of the principle men stood and looked on with as much indifference as if a dog were to be shot down $\&$ when the proper time arrived I rose $\&$ walked off the muzzle of the gun brushing my cheek. 262

The threats continued regularly, prompting Henry Spalding to write to David Greene that he would no longer be able to leave the mission overnight for fear of the lives of Eliza and the children. 263

${ }^{260}$ Drury, Eirst White Women, 227.

261 Warren, 14.

${ }^{262}$ A.B.C.F.M. vol. 248 , vol. $1,283$.

${ }^{263}$ Drury, First White Women, 229. 
Henry and Eliza feared for more than their lives by the mid-1840s; they also feared the effect of their surroundings on their children's lives. When Eliza was nine years old, she was sent to the Whitman station for schooling because she was in constant contact with the Nez Perce children at Lapwaii, and this was not acceptable to the Spaldings. Eliza Spalding Warren later recalled, "I was learning their ways and their language to the detriment of my own."264 Both Eliza and Henry were very concerned about this problem, for they now had not only Eliza, but a newborn son as well. They counteracted the influence of the Native Americans with their children by taking them away from the mission as much as possible. Eliza Warren recalled many winter and summer trips when she and her brother traveled with her father around the region. She recalled that these journeys strengthened their relationship, for it provided them with more private time with their father. She would later write, "the comradship with my father and brother is my dearest memory." 265 Henry Spalding's fears were summed up well in a letter he wrote to a friend in Ohio, when he stated, "Think of bringing up a family of children where there not only is no means of improvement, but when everything is demoralizing, when the child is liable to be insulted or corrupted the moment it steps out of doors."266

The Spaldings' fears developed in the following years, resulting in a strong suspicion of almost all the actions and motives of the tribal members. Henry Spalding appeared to be the most suspicious of the Nez Perce intentions. He did not care to have the Indians inside his house any longer, for he felt that it was necessary to constantly be looking out for what the Nez Perce were doing. He was convinced that if they were not

\footnotetext{
${ }^{264}$ Warren, 14-17.

265 Ibid., 17.

266 Ibid., 74.
} 
in his eyesight, they were stealing or committing some other evil deed $267 \mathrm{He}$ did not feel he could trust any of the Nez Perce, including the chiefs who were once loyal followers of Spalding. ${ }^{268}$ Any type of mishap which may have occurred at the mission, Spalding tended to suspect the tribal members of committing. 269 This attitude, unfortunately, did not improve the bad relations between the Spaldings and the Nez Perce.

Every component of the Spalding mission rapidly began to dissolve after 1845 , with the school house and the church being no exception. Eliza was very ill and close to death a couple of different times during these final years at Lapwaii. Because of her continual poor health Eliza was not readily available to teach at the school, leaving Henry to fill this vacancy. In the fall of 1844 , when he commenced teaching, however, attendance dropped greatly, for there was such little trust in Spalding that the Nez Perce believed that through instruction he would harm them. 270 In 1845 , he reported to the A.B.C.F.M. that at the schoolhouse, "never over 25 attended." He was relieved when Eliza had recovered and commenced teaching again, for she was better liked by the Nez Perce students. ${ }^{271}$ He wrote that the school, which was once the place where calmness remained and success was achieved, was now simply a place for ridicule of the religious teachings and unnecessary, noisy incidents. 272 Similar activities were taking place during prayer services and other religious ceremonies. He wrote on February 3, 1847, "The Sabbath which was once very strictly observed is now generally desecrated."273 This

${ }^{267}$ A.B.C.F.M. vol. 248 , vol. 1, 279-280.

268 Ibid., 282.

${ }^{269}$ Warren, 74.

${ }^{270}$ A.B.C.E.M. vol. 248 , vol. 1, 271.

271 Ibid., 272.

272Ibid., 280.

273 Ibid., 228. 
general attitude of contempt for the church and school is what appeared to have broken the Spaldings' spirit more than any other item. The Nez Perce were not simply rejecting a material object, they were discarding the ideology of what the Presbyterian missions represented. This break in spirit can be viewed clearly when Spalding could no longer put the time and energy into building and teaching, knowing they would mean little or nothing to the Nez Perce. He wrote, "I have not the heart to spend the time $\&$ money putting up a permanent fence, mill-dam or building which to morrow may be torn away." 274

Although the Spaldings did not leave their mission until after the Whitman massacre, it was evident that had they not left when they did, their fait might have been a repeat of the massacre in Wailaptu. At the time of the Whitman massacre, Henry Spalding was on his way home from Wailaptu. He had been at a meeting with Whitman, in which they discussed the possibilities of the Indians of the region rising arms against them. Upon hearing of the massacre, the Nez Perce tribe were split on what path they should take concerning the Spaldings. Some immediately decided to take advantage of the unsettled situation and loot the Spaldings' house, whereas others were worried about the safety of the Spaldings, especially Eliza Spalding, and offered them refuge in their homes. Eliza and Henry, more than anything, were deeply concerned for the welfare of their daughter Eliza who was being held in captivity at the Whitman mission. On December 7 , 1847 , following the release of the captives, Eliza was reunited with her parents at Fort Walla Walla. From this point the decision was made to close the mission and relocate in the Willamette Valley. 275 This was the wisest move the Spaldings had made in many years, for with the exception of a few Nez Perce, they were no longer wanted in the region. One Nez Perce who was devastated to see the Spaldings move out of the area was

${ }^{274}$ Ibid., 182.

${ }^{275}$ Drury, First White Women, 231. 
Timothy, their most loyal convert. Upon hearing of the departure of the Spaldings and the termination of the mission, he stated, "Now my beloved teacher you are passing over my country for the last time. You are leaving us forever and my people, oh my people will see no more light." 276

Similar to the dissolution of both the Jesuit mission among the Flatheads and the Whitman mission with the Cayuse, the Spalding mission's termination had both longterm and short- term causes. The long-term were more similar to the Whitmans' situation, for they were close in proximity and practiced similar methods in their missionary work. The short-term were much more critical, with the most obvious one being the massacre of the Whitmans. That is to say, the short-term explanations were completely decisive in the closing of the mission and superseded the long-term reasons in importance. Other than these explanations there are a few more reasons that Spalding provided to explain why the Nez Perce rejected their missionary work. In his last letters to the Board, he complained insistently about not having enough time to spend with the Natives because of the amount of manual labor he was forced to perform and the negative effect of the incoming Jesuit missionaries.

The Jesuits first started penetrating the Pacific Northwest in the early 1940s, four years after the arrival of the Protestant missionaries. The competition between the two religions for new converts was intense in the following ten years. Spalding was fiercely opposed to the Jesuits' occupancy of areas in the region. He felt that they attempted to sway the Native mind away from Protestant teachings by persuading them that the Presbyterians were not the true messengers of the Lord. In order to counteract this 
movement he and Eliza set forth creating the Protestant Ladder. It was six feet long and two feet wide. He described it as,

representing briefly some of the important events of the world before the christian era $\&$ the crucifixion of Christ I come to Paul whom I represent as pointing to one who has turned off the narrow way where he has left his wife \& children $\&$ with black gown on \& a cross in his hand is just entering the Broad Road. A few of Paul's prophecies concerning the man of sin are translated \& printed as proceeding from his mouth such as he shall forbid to mary \&c After he has left his wife \& entered the Broad Road he is represented as the Pope with a sword in one hand and a torch or fagot in the other . . 277

He proceeds to explain that both Boniface IX and Benidict XIII are portrayed with deadly weapons. In the end Luther is represented as leaving the Broad road and taking the Narrow road with the destination being Heaven. 278 Henry Spalding blamed the dissolution of his mission as well as the Whitman massacre on the Jesuits and their activities. He accused the Jesuits of pointing out the recent deaths of chiefs and blaming that on the Protestants' arrival in the territory. ${ }^{279} \mathrm{He}$ wrote to his superiors that the suffering of the tribe is due to the "unimproved \& the whirlwinds of disorganization \& unrestrained human depravity which are following swift in the train of Immigration \& Romanism." 280 His contempt for the Jesuits is apparent in all his letters to his superiors; therefore, when he used the Catholic order as a scapegoat for the problems of the mission, the accuracy of his statements was dubious.

Spalding also blames the traders of the region for the misconduct of the members of the tribe. He believed them to be without morals or ethics and this lack he assumed

${ }^{277}$ A.B.C.F.M. , vol. 248, vol. 1, 294.

${ }^{278}$ Ibid., 295.

${ }^{279}$ Ibid., 269.

280Ibid., 276. 
they inflicted upon the Nez Perce. There was definitely poor relations between the missionaries and the mountain men, for the missionaries brought white structure and religious morals to the Pacific Northwest and this affected the Indian view on the trappers. 281 When he wrote of the fur traders, he complained of their,

fornication, adultery, polygamy, Sabbath breaking, robbery, infidelity and even friendship and by repeated discharges rallies are pouring down upon us, false reports, calamities, false and fearful insinuations as to our future purposes. They pull every cord, especially the one that vibrated so completely through an Indian's soul, viz: the never can be satisfied desire for property. 282

He accused the trappers of convincing the Nez Perce that the recent outbreak of diseases in the region was a portion of the larger scheme to annihilate the Native Americans. 283 Likewise, with Spalding's accusations aimed at the Jesuits, one can only speculate on the validity of the facts Spalding provides concerning these men.

The most apparent long-term explanation for the dissolution of the Lapwaii mission concerned a lack of time spent with the Nez Perce. For one reason or another, the Spaldings were unable to take enough time truly to inform the Nez Perce of their mission in this region. For the most part this neglect was due to the Spaldings' lack of assistance at the mission. They were required to do all of the cultivation, maintenance, instruction and other necessary chores in order to keep the mission running. Joel Palmer, in his journal, noted that Spalding took on the occupations of a farmer, spiritual leader, teacher and physician. He speculated that because he was forced to divide his time his

${ }^{281}$ Warren, 93.

282 Ibid.

283 Ibid. 
influence was lessened greatly. ${ }^{284}$ Spalding himself described this need for assistance and the negative results of being forced to take on so many different chores. He wrote,

I am now at last after the table has waited long, down \& eating breakfast with one hand, with the other dealing out medecine to 3 women $\& 2$ men who have children sick in their arm or friends at home with my tongue explaining the lesson to a class every morning. 285

His frustration with the amount of work he was expected to accomplish with his small stipend and without aid contributed to his loss of vigor which was noticeable in the final years of the missionaries' existence; as he wrote to his superiors, "I freely admit that the mission ought to plead guilty of neglect of duty $\&$ among the guilty myself should be numbered the first." 286

Eliza Spalding was also busy with instruction of the ever-decreasing number of Nez Perce students, as well as attempting to raise a family. Palmer claimed that it was this aspect that prevented Eliza and Henry most from their work with the Nez Perce. He wrote,

A family of their own is rising around them, which neccessarily requires a portion of their time; and the increasing cares of the family render it impossible to do that amount of good, and carry out fully that policy which they have so advantageously commenced for the natives. 287

The Spaldings conceived two children during their stay at Lapwaii. Raising a family in this region was not simple, for the Spaldings did not care for the influence the Indians had on their children, which was why young Eliza was sent to school at the Whitman mission.

${ }^{284}$ Palmer, 128.

${ }^{285}$ A.B.C.F.M. vol. 248 , vol. $1,278$.

286 Ibid., 276.

287Palmer, 128. 
Eliza Hart Spalding also had difficulties fighting scarlet fever, as well as other diseases in her time spent at the mission. For most of the year of 1844, Eliza was close to death. This resulted in Henry Spalding having to take more time away from religious instruction and act as a doctor to Eliza, as well as assume her portion of the chores. He later also contracted the disease and spent considerable time recovering. 288 Illness and disease definitely had a hand in the Spaldings' unfortunate conclusion to their mission.

Another explanation for the dissolution of the Spalding mission was the simple fact that Henry Spalding was not a well-liked man. From the comments made by Asa Bowen Smith, he was at the very least displeased with the disposition of Henry Spalding. This attitude was shared by many of the Nez Perce chiefs. Although it is rarely stated forthrightly, it is indicated by the developments, such as the drop of attendance in the schoolhouse. Although Henry was disliked by the majority of the Nez Perce, Eliza was, for the most part, regarded as a kind and virtuous woman. In fact, while she was on the brink of death, one of the chiefs stated that if he could, he would give his life for hers. 289

The other long-term explanations are much like that for the Whitmans' situation. Although the Lapwaii mission was not directly on the route of the Oregon Trail, it did have its share of pioneers passing through and settling in the area in the mid 1840s. Most did not stay with the Spaldings, as was the case with the Whitmans, but they stopped long enough to alarm the members of the Nez Perce about the future of their land. They also spread diseases, such as whooping cough, which although not as prominent as it was at Wailaptu, was still an imminent factor in the final rejection of the Spaldings. Simultaneously, though, the Nez Perce complained that not enough whites came through

${ }^{288}$ A.B.C.F.M. vol. 248, vol. $1,253$.

${ }^{289}$ Warren, 15. 
the Nez Perce country and blamed the Spaldings for the lack of trade due to this predicament ${ }^{290}$ Similar to the Whitmans' situation, it could be suggested that the Nez Perce needed a specific white person to blame for their misfortunes caused by the arrival of the emigrants and therefore chose the closest one to them.

There were two basic short-term causes of the dissolution of the mission. The first was the strong influence Tom Hill had on the Nez Perce tribe. Tom Hill was a mixed-blood Delaware who crossed the Plains in the early 1840s. He was renowned for his orical skills, even impressing Dr. Whitman, when he came and spoke to the Cayuse and the Whitmans. ${ }^{291}$ He knew both the English and Sahaptian languages, making him popular among the Native tribes of the region. It is conjectured that upon arriving among the Nez Perce he spoke blasphemous words about the mission and the Protestant religion and many of the Nez Perce took his word as fact. His rhetoric was so persuasive, that close to one hundred lodges acknowledged him as chief and relocated with him. 292 Palmer met with this man and was amazed at the amount of influence he had on the Nez Perce. He condoned stealing and polygamy and made grand promises to make the tribe great. $293 \mathrm{He}$ had competitors, such as Ellis, another chief who attempted to persuade the Nez Perce that Tom Hill was a crazy man, not trustworthy and would lead them astray in the end. He pleaded with his people to come back and listen to the missionaries, but without much success. 294

290Palmer, 130.

291 Sager, 34-35.

${ }^{292}$ Drury, First White Women, 226-227.

293 Palmer, 129.

${ }^{294}$ Ibid., 129-130. 
Tom Hill was not the only troublemaker in this country. Old James and William Craig were two other men who caused great strife for the Spaldings. Craig, for the most part, opposed all whites. He attempted to persuade the Nez Perce that they did not have to listen or obey the laws of the new agent, Elijah White. Old James worked directly against the Spaldings. Upon hearing how white trading and land deals were managed in the East, he demanded payments from the Spaldings for the food and water they were retrieving from Nez Perce land. Although not successful in his venture, his demands would appear ahead of their time. ${ }^{295}$

The final explanation for the closing of the Lapwaii mission was the most immediate. The Whitman massacre caused the termination of the Spalding mission, more so than any other explanation. Although one could convincingly suggest that they would not have remained open much longer, for the White-Indian relations worsened each day, it was the massacre that settled the question whether the Spaldings should continue attempting to religiously enlighten the Nez Perce. Although, their termination was not as fatal and drastic as the Whitman mission, it did have its share of destruction for the Spaldings. Eliza never fully recovered from her poor health and upon moving to the Willamette Valley she did not live more than four years. Henry Spalding, however, remarried, and after the worst years were over in the Indian-White conflicts of the region, he returned to live with the Nez Perce. 


\section{Chapter VII}

\section{Conclusion}

The Flathead, Cayuse and Nez Perce tribes all experienced similar phases as they encountered and lived with the Christian missionaries in the 1830 s and 1840 s. The tribes initially invited the missionaries to live among them, believing that this would improve their living situation, yet they were unaware of the many transformations which would be asked of them in the following years. In the beginning these tribes adhered to these demands and each mission experienced a few years of new accomplishments and great success. As the missionaries witnessed the new cultivation of land, the crowded schoolrooms and the interest in the church and religion, they rejoiced as they believed they had converted a "heathen" aboriginal culture and simultaneously introduced them to civilization. What they did not count on occurring was the third phase, in which for a number of different reasons the tribal members decided that Christianity was not what they had expected, or wanted. Although many Native Americans did adopt Christian traditions, they also continued practicing their old native customs, but this was not accepted by the missionaries. They desired to show these tribes the word of the gospel and display their need for a civilized religion. On this point, though, the Jesuits allowed a little more leeway. An example of this would be Fr. Point's accompanying of the Flatheads on their hunting excursions. Regardless, the three tribes eventually displayed emotions ranging from apathy towards the missionaries to wishing malice upon them. They no longer cared for what the missionaries had to say or teach them, for they had learned that it was very difficult to trust white persons, regardless of their personal religion. 
The Whitmans and the Spaldings were the first missionaries to arrive in the Pacific Northwest. Although they were Presbyterian, most of their instruction was very similar to the Jesuits who came later in 1840 . The Whitmans, who were stationed among the Cayuse, found the tribe willing and ready to learn about the Lord and white civilization. This was somewhat of a misconception, for although the Cayuse were excited to meet the white missionaries, it was their belief that because there was a Doctor among them, he would bring good fortune and would be a able to cure all diseases. They had also heard many good things of the missionaries through the Catholic Iroquois who taught that if one practiced Christianity faithfully, one would live a long and prosperous life. They did not fully comprehend that the Protestant missionaries' purpose was to abolish all Native heathen customs and implement solely Christian and white civilized traditions.

Although some of the tribal members did not welcome the white missionaries in the beginning, they were a minority and often superseded by the majority who were enthralled with the strangers. As the years wore on, though, the novelty of the white missionaries dissolved and resentment was felt by many Natives who believed that their traditional customs were being abandoned for the ways of white civilization. As disease and cold seasons assisted in reducing the size of both the Nez Perce and the Cayuse tribes, blame was placed on the white population which was ever increasing in size. Knowing they could not take on the bulk of the white population, for it had grown so rapidly, they selected those closest to them, who represented the evils of the new white culture. Henceforth, it was the Protestant missionaries who would suffer the greatest hostility from the Natives. 
Various explanations for the Nez Perce and Cayuse turn of temperament have been given in numerous writings as well as in this paper. From these, there are two reasons which stand out as the most obvious and valid. These are the increasing white population in the Pacific Northwest region and the impositions of white civilization's ideals and values on an aboriginal culture. These two explanations developed together in this case, for many white values were implemented in these tribes by the missionaries before the great migration of the 1840 s, but it was not until this time that the Native Americans fully realized the impact this imposition was having on their culture. This predicament was accentuated during the years in which the Whitmans encouraged pioneers who were traveling through the region. It was a general feeling among the Cayuse that the Whitmans were spending more time with the white immigrants than the tribe.

The Jesuits had many experiences among the Flatheads similar to those the Protestants experienced with the Cayuse and Nez Perce. Unlike the Protestants, though, they were sought out by members of the Flathead tribe repeatedly until someone was found of the order who would promise to move west of the Rockies and establish a mission among them. This was Fr. DeSmet, who, al though he lived with the Flatheads, is better known for his overall establishment of Catholic missions throughout the Pacific Northwest. It was Fr. Ravalli and Fr. Mengarini who spent the most time with the Flatheads, learning their language, teaching them cultivation and the word of God and attempting to civilize the tribe into a group of men, women and families similar to those they knew in Europe. 
This final element would prove their downfall, for, like the Protestants, they would find that it is impossible to implement white values in Native culture. Located in the Bitterroot Valley, far from most white pioneer traffic, the Flatheads were spared many of the negative aspects that arose in the mid-1840s. Although they were still afflicted with many of the white diseases that penetrated the region during this period, their death rate did not compare to that of the Cayuse, Nez Perce and other centrally located tribes. This did not halt poor White-Native relations, proving that although disease was one reason for the resentment of white mans' presence in the region, the distrust and enmity sprouted from a much deeper root. The Flatheads rejected the Jesuits just as strongly as the Cayuse and Nez Perce did the Whitmans and Spaldings but their rejection was executed with much less violence and severity. Their decision to exclude the Jesuits from their activities and stop abiding by the word of the "black robes" was not a decisive action. The Jesuit-Flathead relation slowly disintegrated. When the mission was closed in 1849 it was not a surprise to the tribal members, the priests or anyone in the region, for the two parties had been interacting seldom for the past few years. Flathead threats on the Jesuits' lives were few, but danger was one of the primary explanations for their departure as the Flatheads and the Blackfeet had engaged in a series of battles that often threatened the safety of the Jesuits. Lastly, the time appeared correct to leave the mission because news had come to the mission concerning the massacre at the Whitman mission and it was generally concluded that Christian missionaries, on the whole were not desired in the region.

There are multiple documented reasons and explanations for the dissolution of these three missions, as well as others in the Pacific Northwest. 
These observations are all admissible, however this does not confirm that they are the only documented explanations. Through research it is difficult to ignore other factors which have not yet been recognized by historians. The most obvious of these is the apparent competition between the Jesuits and the Protestants for the establishment of one religion in the Pacific Northwest. Their relationship was a strained one filled with competition and paranoia. They both placed a great amount of energy in denouncing the other and attempting to sway the tribes away from their current faith. This caused confusion, disillusionment and skepticism among the tribal members. It aided in their complete mistrust of the missionaries, for it was difficult to have faith in a missionary and simultaneously follow their words of love and caring for one's neighbor.

When Samuel Parker first came west with Dr. Marcus Whitman to observe the Native Americans of the region, it is said that when discovering a cross staked in the ground by a Catholic Iroquois at the place of death of a local Indian, he kicked it down, proclaiming that the cross represented the evils of idolatry which could be found in the Catholic church. 296 This was one of the first instances which represented the battle to establish the true Christian religion among the Pacific Northwest tribes. It can be viewed in letters and journals of both the Jesuits and the Presbyterian missionaries. The Protestants appeared to be more incensed at the arrival of the Catholic missionaries in the region, but this could be attributed to the fact that they were the first missionaries in the region.

${ }^{296}$ Chittenden and Richardson, 380. 
There are countless examples of the Presbyterian fear of a Jesuit takeover in the late 1830s and 1840s. As early as October of 1839, Narcissa Whitman wrote in a letter to her mother of the influence of Catholicism in the region:

A Catholic priest has recently been at Walla Walla and held meetings with the Indians and used their influence to draw all the people away from us. Some they have forbidden to visit us again, and fill all of their minds with distractions about truths we teach, and their own doctrine; Say we have been talking to them about their bad hearts long enough, and too long-- say we ought to have baptized them long ago, etc. etc. The conflict has begun. . 297

She would later complain that among a group of families that migrated to the Northwest in 1841 were twelve Jesuit missionaries. This frightened her as she wrote, "Now we have Catholics on both sides of us."298 She concluded that although they found this situation difficult, they were prepared to endure the Catholic influence and rise above it. 299

Marcus Whitman also complained about the number of Jesuit missionaries in the region and their influence on the Native tribes. He wrote in April of 1843 in a letter to Greene that some of the Cayuse had adopted the "papal form" and left the station. 300 This upset him, for he feared an early demise of his Protestant mission. For the following four years he continued to write the Rev. David Greene of the A.B.C.F.M. concerning the Catholic influence. After receiving sketches of the Flatheads that Fr. DeSmet had drawn himself, he sent them on to his superiors with a warning that many things were to change in the region. 301 He knew that this was the last of the region not to be tainted by papal

297Whitman, Narcissa "Letters Written by Mrs. Whitman From Oregon to her relatives in New York," Oregon Pioneer Association 129.

${ }^{298}$ Ibid., 139.

${ }^{299}$ Ibid.

${ }^{300}$ A.B.C.F.M. vol. 138, vol. $3,705$.

${ }^{301}$ Ibid., 712. 
influences and feared losing the Protestant foothold in the Pacific Northwest. ${ }^{302}$ Later, when negotiating to keep Spalding in his mission, he requested more ministers and laborers at the missions to counteract the "influx of Papists." He wrote that with the completion of these requests, it would aid in "Counteracting papal efforts \& influences." 303 As the years proceeded Whitman became even more fearful of the influence the Catholic missionaries were having on the Native Americans. In a letter to Alonso Hinman he wrote of his fear that the Indians of the Dalles would give their station away to the Jesuits. He wrote, "I hope the Indians will be encouraged to regard the land on the lower plains as the place where they are to plant and not let the Papists have it."304 In the end, he was still plagued by the Jesuits who threatened to open a station in the Walla Walla region if the Cayuse would permit. 305 Whitman offered the Cayuse the option of giving the mission to the Catholic missionaries if that was what the tribe unanimously voted on. They told him at this point that they wished for no such action to take place 306

Whitman not only became upset with the Jesuit missionaries but with anyone who adopted the Catholic faith. Friends of the Whitmans, the Pambruns, assisted the missionary couple greatly during their first years at the mission. Later, however, when Vicar General Blanchet and Rev. Demers traveled through the Cayuse territory they baptized an infant Cayuse and Peter Pambrun, being a Roman Catholic, was pronounced

302 Ibid.

${ }^{303}$ A.B.C.F.M. vol. 248 , vol. 1, 355-357.

${ }^{304}$ Drury, More About the Whitmans, 13.

${ }^{305}$ Sager, 45.

306 Sager, 37. 
godfather. This incident severely agitated Whitman, for the Cayuse were intended to be a Protestant tribe and he felt Pambrun was aiding in the spread of Catholicism. 307

Marcus Whitman's fears concerning the Roman Catholic influence on the Native Americans of the region were valid and fairly rational ones when comparing them to those of Henry Harmon Spalding. Spalding was incensed that they were allowed to establish missions in a region that had been chiefly Protestant up to that time. It was very unusual for Methodists and Presbyterians to work together, for in the past they found it difficult to compromise on particular aspects of instruction. In this instance, however, Henry Harmon Spalding, acknowledging that they had very little hope of excluding the Jesuits from the region, joined forces with the Willamette Methodist mission, run by Jason Lee, in the attempt to keep the Catholics out of the lower Columbia basin. 308 As stated previously, the Catholic missionaries were one of Henry Spalding's explanations for the dissolution of both his and the Whitman mission. It was his belief that the Catholics were at the root of much of the Protestant's misfortunes and poor relations with their respective tribes.

Eliza Spalding was responsible for creating the Protestant ladder under the direction of Henry Spalding. It was devised in order to counteract the Catholic ladder drawn up by Catholic missionaries and to teach the Nez Perce and other tribes that the Protestant path was the only one which reached heaven and the Catholic path would lead

${ }^{307}$ Clarence Booth Bagley, ed. , Early Catholic Missions in Old Oregon Containing Historical Sketches of the Catholic Church in Oregon During the First Forty Years (1838-1878)Blanchet Also Authentic Account of the Murder of Dr. Marcus Whitman and Other Missionaries by the Cayuse Indians of Old Oregon in 1847-Brouillet vol. 1 (Seattle: Lowman \& Hanford, 1932),39.

${ }^{308}$ Berkhofer, 95. 
them to hell. ${ }^{309}$ Spalding in 1846 blamed the suffering of the tribes in the Northwest on a number of things, including: "Americanized heathenism..., the Antimissionaryism from the western states the Hydra headed Jesuitiam from Italy and disappointed Disorganism from the Willamette." $310 \mathrm{He}$ complained that the spirit of "Romanism" was spreading throughout the region uncontrolled. ${ }^{311} \mathrm{He}$ at times even became confrontational and argumentative with the Catholic missionaries about his views on religion and the establishment of it in the Pacific Northwest. Catherine Sager Pringle remembered "Mr. Spalding who by the way is fond of arguing with one of the profession, entered into discourse and found them very sanguine in the hope that this country west of the Rocky mountails being settled by Roman Catholics." 312 His views and his descriptions were colorful and radical, and he believed strongly in them. He believed that because the Protestant missionaries, the true messengers of God, were in the region initially, the established religion should be of their faith

This attitude is a typical one of many Protestant missionaries throughout the world. A Presbyterian entering a Catholic established region, rarely had any regrets, for it was in their belief that unlike other Protestants the Catholic missionaries were evil and a follower of Satan. A common fear among Protestants was that Catholicism would appeal more to the Native mind because of the numerous rituals practiced in the Catholic faith which they considered idolatrous. They believed that the American Indians would be more attracted to the uniformed priest, such as the "black robed" Jesuit, instead of the preacher or minister of the Protestant faiths. This was true in many cases, but the battle

${ }^{309}$ Jaqueline Peterson and Laura Peers, Sacred Encounters Father DeSmet and the Indians of the Rocky Mountain West (Norman: University of Oklahoma Press, 1969), 111.

${ }^{310}$ A.B.C.E.M. vol. 248 , vol. 1, 276.

311 Ibid.

312 Sager, 33. 
for establishment of religion did not exclude the Catholics, who spent as much time persuading different tribes to leave the Protestants and join their faith. 313

Throughout North America there were numerous cases of missionaries competing for the establishment of their religion among the different tribes, until it reached the point where in certain locations the missionaries dominated the Native Americans in number. 314 This attitude was not confined solely to Protestants and Catholics, but also different sects of the Protestant faith. For example, the Presbyterian missionaries often accused the Methodist church of stealing their best missionaries. ${ }^{315}$ This was why it was an exceptional event when the Methodists and the Presbyterian missionaries allied to keep the Jesuits out of their region, for although it was believed best to have only one denomination of the Protestant faith presiding over the region, if that were impossible, the region should at least remain Protestant.

The Jesuits were not innocent bystanders in their attempt to establish the Roman Catholic religion among the Natives of the region. Although, the Jesuit missionaries discussed in this paper did not have a true impact on the Whitman and Spalding missions, they were the beginning of the Catholic settlement in the region. Pierre-Jean DeSmet, Nicholas Point, Gregory Mengarini and Anthony Ravalli as well as the other brothers of the St. Mary's mission rarely came in contact with the Presbyterians, but DeSmet was responsible for establishing twelve missions across the Pacific Northwest. It was when these Jesuit missionaries moved closer to the established Presbyterian missions that the Protestants began to feel the threat of the opposing religion. In the mid-1840s when the

${ }^{313}$ Berkhoffer, 93.

${ }^{314}$ Ibid. 93-95.

315 Ibid. 
Jesuits threatened to move into the Walla Walla and Dalles area, it resulted in paranoia throughout the Whitman and Spalding stations.

The first Catholic missionaries in the general area were French-Canadians, Blanchet and Demers, who were responsible for the creation of the Catholic ladder which was invented in 1838 and later revised by DeSmet in 1843.316 It could be suggested that this chart, which displayed the Protestant faith as a withering and dying branch of the Catholic tree, was the beginning of the poor relations between the two faiths in this region. 317 Fr. DeSmet, when first arriving in the Spokane Valley, immediately criticized the Protestant missionaries for their work. He found it selfish of them to establish their mission a good distance away from the tribe. Ironically, though, the Jesuits of St. Mary's Mission had also built their mission a fair distance from the Flathead camp. He criticized the Protestants' method of cultivating only enough food for themselves to avoid the begging of the Indians. Overall, he was displeased with the situation of the Protestant missionaries, but was delighted to meet with the Spokanes, as he wrote, "A band of Spokanes received me with every demonstration of friendship, and were enchanted to hear that the right kind of Black-robes intended soon to form an establishment in the vicinity."318 It was clear that the Jesuits of St. Mary's shared the same competitive attitude as the rest of the Jesuits in the region, but with the exception of the Walkers and the Eellses in the Spokane region, they did not have much contact with Protestant missionaries.

316Peterson, Sacred Encounters, 111.

${ }^{317}$ Nellie B. Pipes, "The Protestant Ladder," Oregon Historical Ouarterly 37 (September 1936): 237.

${ }^{318}$ Chittenden and Richardson, 379. 
Blanchet published a series of historical sketches regarding the commencement of the Catholic missions in the Pacific Northwest. Even at this early point the competition for the different tribes' attention was evident in his work. Blanchet provides an overview of the Protestant missions in the area upon their arrival. Of them, he had only complaints, including not providing proper care for the Native Americans, trading too often with the white trappers and not spending enough time emphasizing the importance of the Bible ${ }^{319} \mathrm{He}$ concludes his evaluation of these missions by writing,

Such is the character of the work inagurated by missionaries who left the Atlantic slope under the hallucination that they were called to preach salvation to those that sat in darkness and in the shadow of death, but whose trading propensities overcame their religious zeal, until finally the cause of Christianity was wrecked on the shoals of self-aggiandizement. 320

The claims that Spalding and Whitman made against the Jesuits in the mid-1840s should only be considered when taking into account their worsening situation and inherent biases. Spalding believed that the Jesuits were taking advantage of the native mind, by pointing out that the elders of the Nez Perce tribe had all died since the coming of the Protestant missionaries and directly placing the blame of this circumstance upon the Presbyterian missionaries. They were aware that the Nez Perce spiritual belief was that death could be caused by medicine men or women, and Spalding believed that the Jesuits pointed to the Protestant missionaries as the empowered ones. 321

A meeting between the Cayuse and the Jesuits occurred at Fort Walla Walla where the Jesuits attempted to push themselves into the Protestant territory. Two of the

${ }^{319}$ Bagley, Early Catholic Missions, 14-17.

${ }^{320}$ Ibid., 17.

${ }^{321}$ A.B.C.F.M. vol. 248 , vol. $1,269$. 
Cayuse Indians offered the Whitman mission to the Jesuits. ${ }^{322}$ This would appear to have been a hint that in the future the Protestant missionaries were to be eliminated. After the meeting, Henry Spalding spoke with chief Piyu-Piyu Muks-Muks, of the Walla Walla tribe. He reported that "the Catholics had often urged him to leave the Protestants and join with them, but that he would never join them; it was too much like his old religion, worshipping men, women, clothes, swords, etc."323 There was also speculation on whether the Jesuits were aware of the Whitman massacre before it occurred. Spalding believed that they knew of it and were the cause of it, due to rumors which they started of Dr. Whitman poisoning the tribe ${ }^{324}$ It is possible that the Jesuits did know of it, but this would not have been peculiar, for many whites in the region were aware of the Cayuse's general opinion of the Whitmans and their violent tendencies. Joseph Stanfield, a Roman Catholic, who was employed at the Whitman station was aware of the murderous plot but failed to warn any of the missionaries. 325

What can be confirmed is that the Jesuits certainly did desire to establish their faith as the primary religion in the region. DeSmet and Point on their journey overland to the Bitterroot Valley dreamed of making the Pacific Northwest a replica of the Jesuits' successful mission among the Guarani Indians of Paraguay in the Seventeenth Century. 326 The only method of which they knew how to accomplish this task was assist in the dissolution of the Protestant missions. Public criticism of the Presbyterian missionaries' customs and practices appeared to be the first step to reaching this goal.

322 Sager, 45.

${ }^{323}$ Ibid., 40.

${ }^{324}$ E.G. Bourne, "The Legend of Marcus Whitman," American Historical Review 6 (October 1900): 281.

${ }^{325}$ Sager, 46-47.

326 Peterson, 84. 
DeSmet, after spending a short amount of time with the Flatheads, felt the need to move on to other tribes in the region and observe their needs. He had no qualms about opening up missions up in the vicinity of Protestant missions, for the Jesuits for the most part had always followed other religions in their missionary work. 327 This can be proved by viewing the rapid expansion of missions that opened throughout the Pacific Northwest. They opened a mission in Coeur d'Alene, only thirty miles outside of Spokane, where the Walkers and Eellses were stationed. They were looking to establish another mission in Walla Walla near the time of the massacre, as well as constructing a station in the Dalles area. They were moving throughout the Oregon country fast and with temporary success in most missions, but similar to the Protestant missions, very few of them endured the poor white-Indian relations that took place during the mid and late 1800 s.

The interaction between the two religions did not appear to affect the Flatheads as it did the Nez Perce and Cayuse. This can be attributed to the fact that the geographical location of the Flatheads made it impossible for them to be in contact with the Protestant missionaries. Although the Flatheads did meet Parker and Whitman on their first excursion west in 1835 , they had already completed at least two journeys to St. Louis in search of the "Black Robes" and they were prepared to await the coming of these Catholic missionaries.

The Cayuse and the Nez Perce were the tribes that most likely suffered from the disillusionment of the conflicting religions. They used the Jesuit-Protestant poor relationship to their advantage. Ironically, when the relations between the Protestant 
missionaries and the Native Americans worsened, the Jesuits arrived in their territory. The Indians, having become disillusioned with the Protestant missionaries, found temporary solace with the Jesuits. Whitman commented that some of the Cayuse had even converted to Catholicism. The Cayuse and Nez Perce, knowing the circumstances at hand, threatened the missionaries with Catholic conversion and complete withdrawal from the mission. Also it was believed that the Jesuit missionaries informed the Cayuse that the many deaths caused by the measles were a result of the presence of the missionaries. Spalding claimed that Timtimmissi, a Cayuse chief, told Dr. Whitman and Henry Spalding that the "Samh Sismusisma" (black gowns) were spreading these rumors and although he did not believe them, many of his people did. ${ }^{328}$ By the time of the massacre, though, neither tribe cared particularly for either religion, for both attempted to transform their lifestyles into something for which they were not prepared.

Having two religions, both claiming to be the only true religion of Christ, would have been confusing for any aboriginal tribe to digest. Then to have these two Christian bodies compete with one another for the conversion of the tribes of the Pacific Northwest, denounce one another, and find it incapable to share the same land would prove even more perplexing. It would not only leave the tribes in a state of disillusionment, but it would decrease both religions' validity as being true messengers of God. The Native Americans were taught that they were all children of the same God and then were faced with a choice of faiths. Spalding claimed that Ellis, the principle chief of the Nez Perce, did not want two Christian religions among his tribe as he said, "It will do for the French and English to have two religions as they have laws. But for Indians who have no laws it will not do." 329 This dilemma was also recognized but not acted upon by

${ }^{329}$ Catherine Pringle Sager "Reminiscences" [typescript], Mss\#1194 p.1, Special 
the Bishop of Juliopolis when asked to send Catholic missionaries to the Willamette Valley in the mid 1830s. His initial response was negative as he recognized that "they were in the country Anglican, Methodist and Presbyterian ministers, the difference of teachings might create dissensions among the Indians." 330 Only a year after this statement, however, the bishop conceded to establish a mission in the valley despite the presence of other religious missionaries. 331 This dilemma was without doubt recognized by many to have negative effects on the tribes, but nothing was done to halt further similar occurrences.

How this affected the different tribes being studied is difficult to determine due to a lack of primary evidence. Their actions, though, provide enough proof that the tribes were frustrated with both religions. They took advantage of both religions by threatening them with a turn of faith if they did not get their way. The different missionaries taught them to act civilized. They were not to fight with their neighbors and yet it seemed hypocritical of any of them to preach when they could not practice themselves. This lead to general confusion among the tribes and a lack of respect for the missionaries who could not live up to stand by what they themselves preached. Their frustration is visible when viewing the steady decline of the Natives' participation in religious ceremonies in the final years. Although the conflict for the establishment of religion in the Pacific Northwest could not be considered one of the primary explanations for the Native rejection of the missionaries, it could explain why the different tribes discarded Christianity so readily in this period.

Collections, Oregon Historical Society Library, Portland, Or. ${ }^{330}$ Bagley, 62.

331 Ibid. 
The missionaries did not travel west with the intentions of damaging the Native American heritage. They all believed they were improving the lives of the Pacific Northwest tribes in extraordinary measures. They sacrificed everything considered' normal in an American life and moved across the country to a region which was untamed and scarcely inhabited by white persons. This was not easy for any of them, and can be viewed especially in Narcissa Whitman's letters and diary. Thousands of years of customs and traditions could not possibly be eliminated in a few years. This is a notion that has been proven time and time again throughout history. Although, in hindsight it appears that the missionaries' actions were naive and their goals completely unrealistic, at the time they could see no other choice. Christianity had a powerful hold on all of the missionaries and their desire to do right by the Lord, disabling them from clearly surveying any negative ramifications their actions might have. 


\section{Works Cited}

\section{Primary Sources}

American Board Commision of Foreign Affairs Letters and Papers Oregon Indians 1843-1859, vol. 138 and vol. 238, vol. 1-3.

"How the Old Mission of St. Mary's was Founded Responsive to the Earnests Appeals of the Indian Emissaries-The Jesuit Fathers Penetrated the Wilderness of the Rocky Mountains Sixty Years Ago." Anaconda Standard. 17 December 1899, 40-42.

Bagley, Clarence Booth, ed. Early Catholic Missions in Old Oregon containing Historical Sketches of the Catholic Church in Oregon During the First Forty Years(1838-1878)-Blanchet Also Authentic Account of the Murder of Dr. Marcus Whitman and Other Missionaries by the Cayuse Indians of Old Qregon in 1847-Brouillet. vol. 1. Seattle: Lowman \& Hanford, 1932.

Baurum, O. Bel to Edmund T. Dunne, 26 July 1872. Transcript in the hand of the Society of Jesus. The Pacific Northwest Tribes Missions Collection of the Oregon Province Archives of the Society of Jesus. Foley Library. Gonzaga University, Spokane.

Biddle, Nicholas and Paul Allen. History of the Expedition Under the Command of Captains Lewis and Clark, to the Sources of the Missouri, thence Across the Rocky Mountains and Down the River Columbia to the Pacific. 2 vols. Philadelphia: Bradford \& Inskeep, 1814.

H.M. Chittenden, A.T. Richardson, ed. Life, Letters and Travels of Father Pierre-Jean DeSmet, S.J. 1801-1873Missionary Labors and Adventures among the Wild Tribes of the North American Indians Embracing Minute Description of Their Manners, Customs, Games, Modes of Warfare and Torture, Legends, Tradition, etc. All from Personal Observations Made during Many Thousand Miles of Travel, with Sketches of the Country St. Louis to Puget Sound and the Altabasca., vol.1-4. New York: Francis P. Harper, 1904.

Cox, Ross. The Columbia River or Scenes and Adventures during a Residence of Six Years on the Western Side of the Rocky Mountains, ed. Edgar Stewart and Jane Stewart. Norman: University of Oklahoma Press, 1957.

Drury, Clifford Merrill, ed., The Diaries and Letters of Henry H. Spalding and Asa Bowen Smith Relating to the Nez Perce Mission 1838-1842. Glendale, Ca.: The Arthur H. Clark Co., 1958. 
-------, ed., The First White Women Over the Rockies. vols. 1-2 Glendale, Ca: The Arthur H. Clark Co., 1963

-------, ed., More About the Whitmans, Four Hitherto Unpublished Letters of Marcus \& Narcissa Whitman. Tacoma: Washington State Historical Society Press, 1979.

Dunbar, Seymour, ed. The Journals \& Letters of Major John Owen, pioneer of the Northwest. vol. 1-2. New York: Eberstadt, 1927.

Elliot, T.C. "What Doctor Marcus Whitman in Person Requested at Boston on March 30, 1843." Oregon Historical Quarterly 22 (December 1921): 49-60.

Gray, William H. A History of Oregon, 1792-1849 Drawn from Personal Qbservation and Authentic Information. Portland: Harris \& Holman, 1870.

Hawn, Laura A. Patterson. "Recollections, 1843" [handscript]. Special Collections, Oregon Historical Society Library, Portland, Oregon.

Joset, Joseph. "Chronology of Rocky Mountain Region" transcript in the hand of Society of Jesus. The Pacific Northwest Tribes Missions Collections of the Oregon Province Archives of the Society of Jesus. Foley Library. Gonzaga University, Spokane.

Leonard, Zenas. Narrative of the Adventures of Zenas Leonard, ed. Milo Milton Quaife. Chicago: Lakeside Press, 1934.

Mengarini, Gregory. Recollections of the Flathead Mission. Glendale: Arthur H. Clark Co., 1977

Newell, Robert. Memoranda: Travles in the Teritory of Missourie; Travle to the Kayuse War; Togethor with A Report on the Indians South of the Columbia River. ed., Dorothy O. Johansen. Champoeg Press, 1959.

Palladino, Lawrence B., S.J. Anthony Ravalli, S.J. Forty Years a Missionary in the Rocky Mountains Memoirs. Helena: Geo E. Boos \&Co. Printers, 1884.

Palmer, Joel. Journal of Travels over the Rocky Mountains. March of America Facsimile Series. Ann Arbor: University Microfilms Inc., 1966.

Parker, Samuel. Journal of an Exploring Tour Beyond the Rocky Mountains Under the Direction of the A.B.C.F.M . with a Map of Oregon Territory. New

York: Derby \& Co., 1846. 
Point, Nicholas. Wilderness Kingdom, Indian Life in the Rocky Mountains 18401847; the Journals \& Paintings of Nicholas Point trans. and intro. by Joseph P. Donnelly. New York: Holt, Rinehart \& Winston Press, 1967.

Ravalli, Anthony to Lawrence B. Palladino, 8 December 1879. Transcript in the hand of the Society of Jesus. The Pacific Northwest Tribes Missions Collection of the Oregon Province Archives of the Society of Jesus. Foley Library. Gonzaga University, Spokane.

-------, "History of Rocky Mountain Missions." Unfinished manuscript. The Pacific Northwest Tribes Missions Collection of the Oregon Province Archives of the Society of Jesus. Foley Library. Gonzaga University, Spokane.

Sager, Catherine, Elizabeth Sager, Matilda Sager. The Whitman Massacre of 1847. Fairfield, WA.: Ye Galleon Press, 1981.

Talbot, Theodore. The Journals of Theodore Talbot 1843-1852, with the Fremont Expedition of 1843 and with the First Military Company in Oregon Territory. ed. Charles H. Carey, Portland, Oregon: Metropolitan Press, 1931.

Thompson, David. David Thompson's Narrative: 1784-1812, with introduction and notes by Richard Glover. Toronto: Champlain Society, 1962.

Townsend, John Kirk. Narrative of a Journey Across the Rocky Mountains to the Columbia River. with an Introduction by Donald Jackson. Lincoln: University of Nebraska Press, 1978.

Warren, Eliza Spalding. Memoirs of the West, Spaldings. Portland, Or.: Marsh Printing Co., 1916.

\section{Secondary Sources}

Aveling, John Cedric H. The Jesuits. New York: Stein \& Day, 1982.

Berkhofer, Robert F. Jr.. Salvation and the Savage An Analysis of Protestant Missions and American Indian Response, 1787-1862. Lexington: University of Kentucky Press, 1965.

Bourne, Edward G. "The Legend of Marcus Whitman." American Historical Review 6 (October 1900): 277-285.

Burns, Robert Ignatius, S.J.. The Jesuits and the Indian Wars of the Northwest. New Haven: Yale University Press, 1966. 
Cocks, James Fraser. The Selfish Savage: Protestant Missionaries and Nez Perce and Cayuse Indians, 1835-1847. Ann Arbor: University Microfilms International, 1975.

Davis, W.L. "Peter John DeSmet The Journey of 1840." Pacific Northwest Quarterly 35 (January 1944): 32-36.

Doray, Sister Mary Jean. "Old Tale Tells How Mary Came Christmas Eve to the Rockies." Eastern Montana Register. 24 December 1950, 1.

Eells, Myron D.D. A Reply to Professor Bourne's "The Whitman Legend". Walla Walla: Statesman Publishing Co., 1902.

Elliot, T.C. "The Coming of the White Women, 1836, Part IV." The Oregon Historical Quarterly. 38 (March 1937).

Fahey, John. The Flathead Indians. Norman: The University of Oklahoma Press, 1974.

Haines, Francis. The Nez Perce: Tribesmen of the Columbia Plateau. Norman: University of Oklahoma Press, 1955.

Hovey, Reverend. Interviewed by author, 25 May 1994. Portland, Oregon. tape recording. Oregon Historical Society, Portland.

Howard, Hellen Addison. "Versatile Missionary." Catholic Digest. (February 1940). The Pacific Northwest Tribes Missions Collection of the Oregon Province Archives of the Society of Jesus. Foley Library. Gonzaga University, Spokane.

Jeffrey, Julie Roy. Converting the West; A Biography of Narcissa Whitman. Norman: University of Oklahoma Press, 1991.

Jessett, Thomas E. "Anglicanism Among the Indians of Washington Territory." Pacific Northwest Quarterly. 42 (July 1951): 224-240.

Josephy, Alvin M. Jr. The Nez Perce Indians and the Opening of the Northwest. New Haven: Yale University Press, 1965.

Lyman, H.S. "Items from the Nez Perce Indians." Oregon Historical Quarterly. 2 (March 1901-December 1901):

Marshall, William I. Acquisition of Oregon and the Long Suppressed Evidence About Marcus Whitman. vol. 2, Seattle: Lowman \& Hanford Co. Printers, 1905. 
"Montana's First White Settlement at Stevensville by Missionaries." Stevensville Register. 23 December 1909, 17.

Peterson, Jacqueline and Laura Peers. Sacred Encounters Father DeSmet and the Indians of the Rocky Mountain West. Norman: University of Oklahoma Press, 1993.

Ray, Verne F. Ethnohistory of the Joseph Band of Nez Perce Indians: 1805-1905. A Garland Series: American Indian Ethnohistory Indians of the Northwest. Horr: Garland Publishing C., 1974.

Ronan, Peter. Historical Sketch of the Flathead Nation. Minneapolis: Ross \&Haines, Inc., 1965.

Ross, Alexander. Adventures of the First Settlers on the Oregon or Columbia River. Edited by Milo Milton Quaife. New York: The Citadel Press, 1969.

Santee, J.F. "Lawyer of the Nez Perces." Washington Historical Quarterly. 25 (January 1934): 39-41.

Schaeffer, Claude. "The First Jesuit Mission to the Flathead, 1840-1850: A study in Culture Conflicts." Pacific Northwest Quarterly. 28 (July 1937): 234-249.

Schoenburg, Wilfred P. Jesuits in Montana, 1840-1960. Portland, Or.: Oregon Society of Jesuit Press, 1960.

-...-.. Paths to the Northwest: A Jesuit History of the Oregon Province. Chicago: Loyola University Press, 1982.

Scott, Leslie M. "Indian Women as Food Providers and Tribal Counselors." Oregon Historical Quarterly. 42 (September 1941):

Taylor, Walter Ed. "Flatheads Trekked 800 Miles to Welcome Fr. DeSmet When he Came to Found their Mission." The Hardin Tribune Herald., 5. 